\title{
STRUCTURAL REFORM AND PRODUCTIVITY GROWTH IN EMERGING EUROPE AND CENTRAL ASIA
}

Yordan Georgiev, Piroska Nagy-Mohacsi, and Alexander Plekhanov

NO. 523

October 2017
ADB ECONOMICS WORKING PAPER SERIES 
ADB Economics Working Paper Series

\section{Structural Reform and Productivity Growth in Emerging Europe and Central Asia}

Yordan Georgiev, Piroska Nagy-Mohacsi, and Alexander Plekhanov

No. 523 | October 2017
Yordan Georgiev (Yordan.Georgiev@bankofengland.co.uk) is an Economist at the Bank of England. Piroska NagyMohacsi (P.Nagy-Mohacsi@Ise.ac.uk) is Programme Director in the Institute of Global Affairs at the London School of Economics. Alexander Plekhanov (plekhana@ebrd.com) is an Associate Director, Deputy Director of Research at the European Bank for Reconstruction and Development.

This paper has been prepared as background material for the Asian Development Outlook 2017 theme chapter on Transcending the Middle-Income Challenge under the guidance of Donghyun Park. The authors are grateful to Erik Berglof, Sergei Guriev, Era Dabla-Norris, Donghyun Park, Jeromin Zettelmeyer, and participants of a seminar at the London School of Economics for their valuable comments and suggestions. The views expressed in this publication are those of the authors and do not necessarily reflect the views and policies of their respective institutions. 
(C) 2017 Asian Development Bank

6 ADB Avenue, Mandaluyong City, 1550 Metro Manila, Philippines

Tel +632632 4444; Fax +6326362444

www.adb.org

Some rights reserved. Published in 2017

ISSN 2313-6537 (Print), 2313-6545 (electronic)

Publication Stock No. WPS179102-2

DOI: http://dx.doi.org/10.22617/WPS179102-2

The views expressed in this publication are those of the authors and do not necessarily reflect the views and policies of the Asian Development Bank (ADB) or its Board of Governors or the governments they represent.

ADB does not guarantee the accuracy of the data included in this publication and accepts no responsibility for any consequence of their use. The mention of specific companies or products of manufacturers does not imply that they are endorsed or recommended by ADB in preference to others of a similar nature that are not mentioned.

By making any designation of or reference to a particular territory or geographic area, or by using the term "country" in this document, $A D B$ does not intend to make any judgments as to the legal or other status of any territory or area.

This work is available under the Creative Commons Attribution 3.0 IGO license (CC BY 3.0 IGO)

https://creativecommons.org/licenses/by/3.0/igo/. By using the content of this publication, you agree to be bound by the terms of this license. For attribution, translations, adaptations, and permissions, please read the provisions and terms of use at https://www.adb.org/terms-use\#openaccess

This CC license does not apply to non-ADB copyright materials in this publication. If the material is attributed to another source, please contact the copyright owner or publisher of that source for permission to reproduce it. $A D B$ cannot be held liable for any claims that arise as a result of your use of the material.

Please contact pubsmarketing@adb.org if you have questions or comments with respect to content, or if you wish to obtain copyright permission for your intended use that does not fall within these terms, or for permission to use the ADB logo.

Notes:

1. In this publication, " $\$$ ” refers to US dollars.

2. ADB recognizes "Russia" as the Russian Federation.

3. Corrigenda to ADB publications may be found at http://www.adb.org/publications/corrigenda 


\section{CONTENTS}

TABLES AND FIGURES

ABSTRACT V v

$\begin{array}{ll}\text { I. INTRODUCTION } & 1\end{array}$

II. REFORMS AND PRODUCTIVITY IN EMERGING EUROPE AND CENTRAL ASIA 2

A. Patterns of Convergence 2

B. Evolution of Total Factor Productivity 3

C. Quantifying the Impact of Structural Reforms 6

III. SPEED AND SEQUENCING OF STRUCTURAL REFORM 9

A. Broad Trends 9

B. Generations of Reforms 11

C. Generations of Reform in a Neo-Schumpeterian Perspective 11

D. Factors Facilitating Structural Reforms 13

E. $\quad$ Outlook for Growth and Reform 17

IV. STRUCTURAL REFORMS, INEQUALITY, AND LIFE SATISFACTION $\quad 18$

A. Socioeconomic Cost of Transition Reforms 18

B. Structural Reforms and Inequality 20

V. CONCLUSION $\quad 22$

$\begin{array}{ll}\text { APPENDIX } & 25\end{array}$

$\begin{array}{ll}\text { REFERENCES } & 31\end{array}$ 


\section{TABLE AND FIGURES}

TABLE

Structural Reforms and Fiscal Stance, 2000-2014

\section{FIGURES}

$1 \quad$ Average Income Per Capita in Emerging Europe and Central Asia 2

2 Average Income Per Capita in Central Europe 2

3 Real Gross Domestic Product Growth 3

$4 \quad$ Per Capita Income at Purchasing Power Parity and Total Factor Productivity in $1993 \quad 4$

$5 \quad$ Share of Services in Gross Domestic Product 4

6 Cumulative Growth, 1993-2010 5

$7 \quad$ Capacity Utilization in the Industry 5

$8 \quad$ Average Transition Indicators and World Governance Indicators, $1996 \quad 7$

9 Average Transition Indicators and World Governance Indicators, 2014

10 Evolution of Gross Domestic Product Per Worker in Baseline and Reform Scenarios 8

11 Average Country Transition Indicator 10

12 Average Sector Transition Indicators: Balance of Upgrades and Downgrades 10

13 Average Country Transition Indicators 11

14 Shares of Global Trade and Gross Domestic Product 13

15 Shares of Exports that Are Part of a Global Value Chain 14

16 Change in Average Worldwide Governance Indicator 14

17 Average Net Nonresident Private Capital Flows $\quad 15$

18 Share of Foreign Banks in Total Bank Assets 16

19 Per Capita Income at Purchasing Power Parity and Total Factor Productivity, $2007 \quad 17$

20 Cumulative Contraction in Real Gross Domestic Product 19

$21 \quad$ Average Height by Year of Birth 20

22 Percentage of Respondents Who Are Satisfied with Life and Per Capita Income 20

23 Percentiles of Population with Below-Average Income Growth, 1989-2016 21 


\begin{abstract}
Since 1990, countries in emerging Europe and Central Asia have undergone comprehensive economic transformation. These reforms helped achieve an impressive degree of income convergence toward the levels of the advanced economies, although at the cost of rising inequality and lower life satisfaction. Over the last decade, both the speed of reforms and economic growth have slowed down markedly. To sustain convergence, greater emphasis needs to be put on structural reforms, facilitating innovation and boosting firm productivity while, at the same time, taking into account the distributional impact of reforms.
\end{abstract}

Keywords: economic growth, structural reform, transition

JEL codes: O57, P24 


\section{INTRODUCTION}

Since 1990, countries in emerging Europe and Central Asia have undergone comprehensive economic transformation, and achieved an impressive degree of income convergence toward the levels of the advanced economies, albeit at the cost of rising inequality and lower life satisfaction. ${ }^{1}$ Over the last decade, the speed of reforms has slowed down markedly and, in some cases, reform reversals became common, reflected in countries in the region being downgraded in terms of various cross-country measures of economic and political institutions (European Bank for Reconstruction and Development [EBRD] 2013; and Lehne, Mo, and Plekhanov 2014).

This paper revisits the experience with economic growth, income convergence, and structural reforms in emerging Europe and Central Asia, taking into account both the unique transition experience of the early 1990s and the most recent developments following the 2008-2009 global financial crisis. It looks at the nature of the reforms and their impact on productivity growth, and draws insights with respect to the future path of income convergence for the region's economies.

The paper also aspires to contribute to the ongoing research on how to avoid the "middleincome trap" or "nonconvergence trap"-the notion that going from middle- to high-income status will require capabilities different from those required at previous stages of development and that countries often experience a severe slowdown in growth rates as they try to make this transition. Transition economies are of particular interest in this regard because, out of only a handful of countries globally that have made it to the high-income group since the start of the 21 st century, many were in Central Europe.

The analysis shows that a number of factors contributed to the rapid income growth between the mid-1990s and 2008, including better utilization of existing physical and human capital; entry into the European and global value added chains; deepening of economic and political integration with the European Union (EU)-15 economies that supported upgrading of economic and political institutions; and rapid entry of foreign banks and the credit boom that accompanied it. Several countries, clustered in Central Europe, made it to high-income group (using the World Bank definition) in a historically short time. Yet, by the time of the 2008-2009 financial crisis, all these drivers had been largely exhausted. Hence, the need for the region to pursue a modified growth model.

The challenges faced by the region today are more akin to those faced by middle-income countries elsewhere, even though certain legacies of the central planning and the early transition experience persist in shaping today's attitudes toward markets and democracy as well as government policies.

The rest of the paper is structured as follows. Section II reviews the region's growth experience since the early 1990s and the role of structural reforms. Section III discusses the patterns of structural reforms in emerging Europe and Central Asia and their drivers. Section IV examines the cost of structural reforms in terms of higher inequality, physical suffering, and life satisfaction with particular reference to sustainability of reforms. Section $\vee$ concludes and discusses implications of emerging Europe's experience for emerging markets in Asia and elsewhere.

\footnotetext{
The analysis covers Albania, Armenia, Azerbaijan, Belarus, Bosnia and Herzegovina, Bulgaria, Croatia, the Czech Republic, Estonia, Macedonia (former Yugoslav Republic), Georgia, Hungary, Kazakhstan, Kosovo, the Kyrgyz Republic, Latvia, Lithuania, Moldova, Montenegro, Poland, Romania, the Russian Federation, Serbia, the Slovak Republic, Slovenia, Tajikistan, Turkmenistan, Ukraine, and Uzbekistan.
} 


\section{REFORMS AND PRODUCTIVITY IN EMERGING EUROPE AND CENTRAL ASIA}

\section{A. Patterns of Convergence}

Following the initial transition recession, the emerging Europe and Central Asia region experienced fast rates of income convergence toward the levels of the Group of Seven (G7) advanced economies. At the same time, this convergence was interrupted by the 2008-2009 global financial crisis. After the initial postcrisis blip in 2009/2010, income convergence has returned, but at a slower rate (Figure 1), although this slowdown was somewhat less pronounced in Central Europe (Figure 2). In part, this pattern reflects broader trends in emerging markets (including the People's Republic of China, Figure 3). At the same time, various region-specific factors also played an important role.

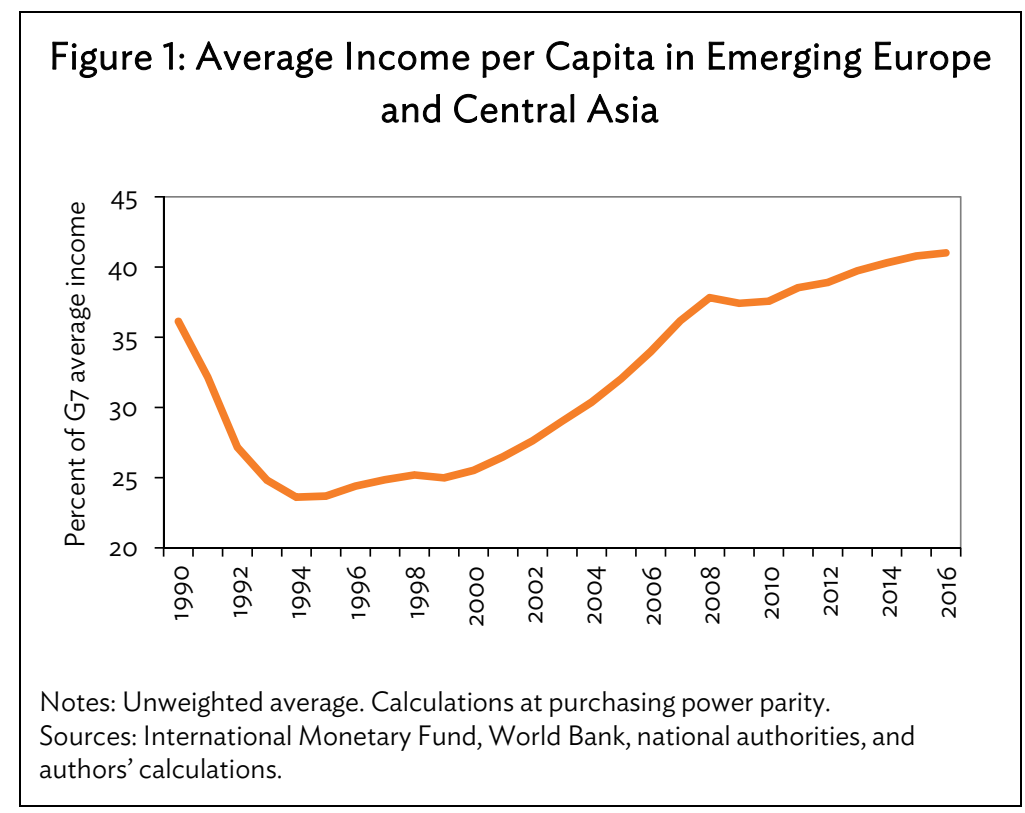

Figure 2: Average Income per Capita in Central Europe

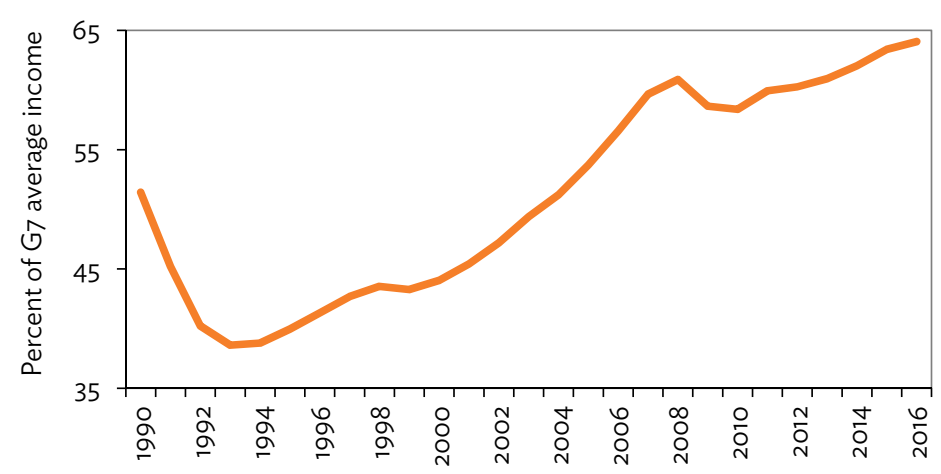

Notes: Simple average of Croatia, the Czech Republic, Estonia, Hungary, Latvia, Lithuania, Poland, the Slovak Republic, and Slovenia. Calculations at purchasing power parity.

Sources: International Monetary Fund, World Bank, national authorities, and authors' calculations. 


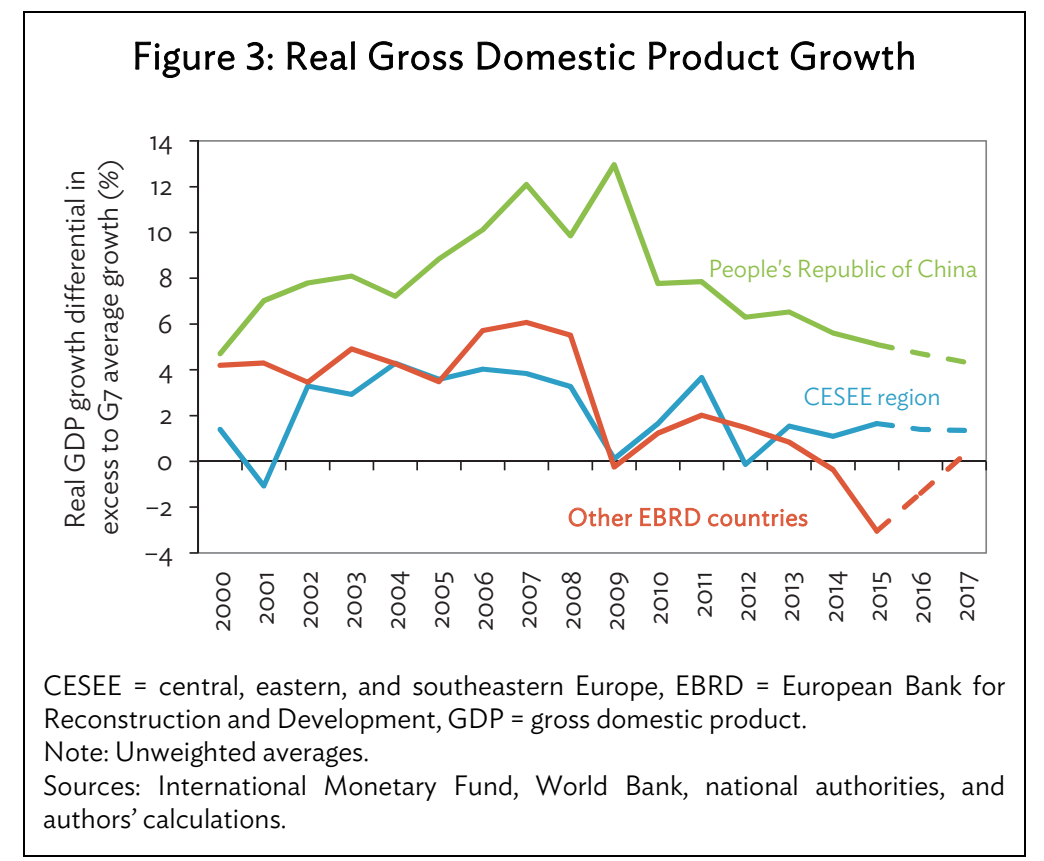

\section{B. Evolution of Total Factor Productivity}

The region's experience of growth and structural transformation has been fairly unique, given its starting point in the late 1980s. The central planning economies accumulated relatively high levels of physical and human capital (by the standards of developing and emerging market economies). Yet, in the absence of market principles and price signals, these resources were often combined inefficiently, resulting in low levels of total factor productivity (TFP) - the "residual" productivity once labor and capital have been accounted for. TFP is typically derived from the Cobb-Douglas production function with constant returns to scale, which includes labor force, the human capital index based on the total years of schooling, and the stock of physical capital.

Based on estimates using Penn World Tables data, back in 1993, the region's economies had TFP levels well below those of emerging market economies with similar levels of per capita income (Figure 4).

The initial set of reforms was implemented shortly after the fall of the Berlin Wall (in 1989) and the dissolution of the Union of Soviet Socialist Republics (in 1991). These reforms aimed at introducing market interactions with supportive institutions, and eventually boosting TFP. They included liberalization of prices, liberalization of interest rates and international trade, privatization of large enterprises, privatization of small and medium-sized enterprises, laying the foundations of corporate governance, and establishing competition rules in the newly forming markets. Further reforms aimed at establishing markets in the infrastructure sectors and regulated industries, such as railroads, municipal transport and telecommunication, as well as the development of capital markets, nonbank financial services, and redesign of pension systems. 


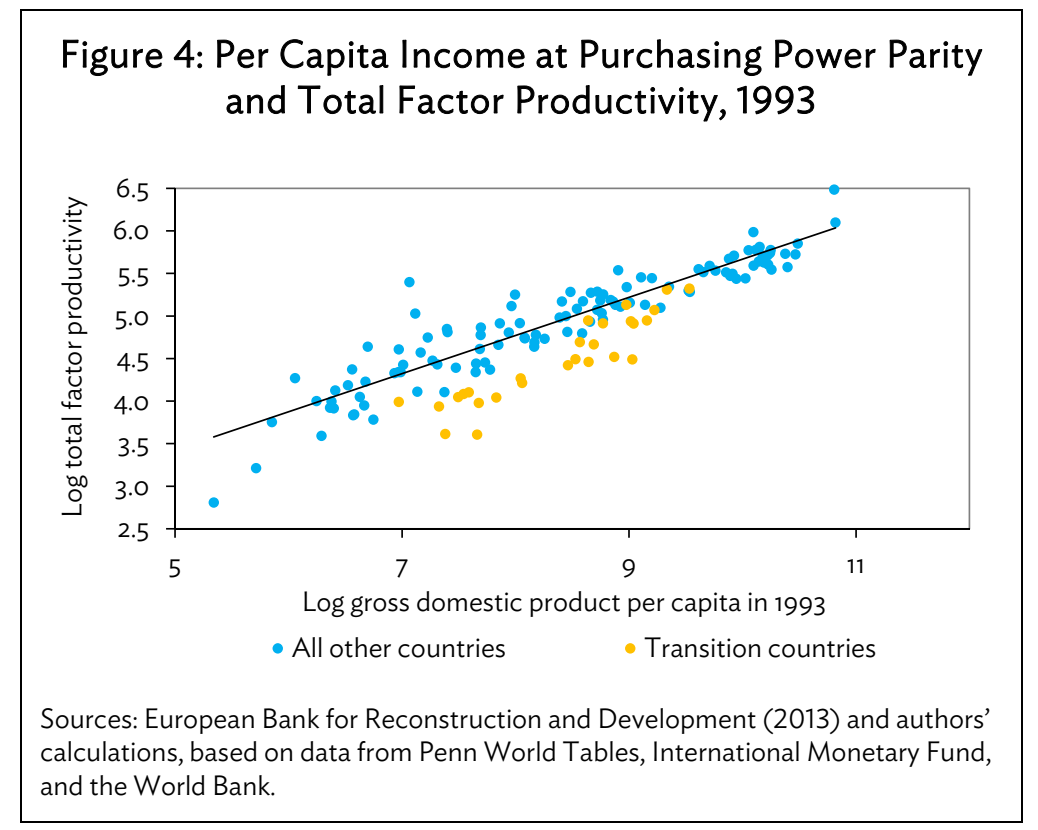

The reforms took place alongside a very fast structural transformation away from manufacturing and agriculture, and toward a greater role of services. While many other emerging markets, including the People's Republic of China, have been undergoing this shift from a similar point of departure in terms of the starting levels of services value-added-to-gross domestic product (GDP) ratio (of 35\%-40\%), the pace of transformation in emerging Europe was uniquely high, with services-to-GDP ratio increasing to $55 \%-60 \%$ in a span of several years in many countries, including the Russian Federation (Figure 5).

Figure 5: Share of Services in Gross Domestic Product

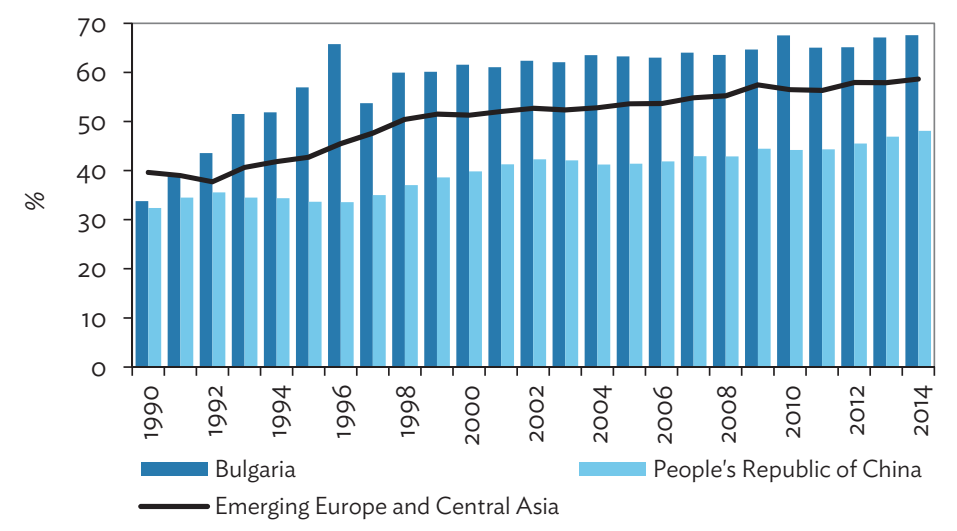

Sources: European Bank for Reconstruction and Development (2016) and authors' calculations.

As countries emerged from the initial transition recession, the catch-up in terms of TFP levels enabled by the broad market-oriented reforms was the single most important factor that supported fast income convergence between the mid-1990s and the end of the next decade (Figure 6). No other region experienced such fast productivity growth as the transition region. We note that part of the estimated improvement in TFP may be due to better capacity utilization in the industry, as utilization rates 
plummeted during the transition recessions of the early 1990s. Both new investment in upgrading existing capacity and establishment of new supply chains helped to raise capacity utilization over time (Figure 7).
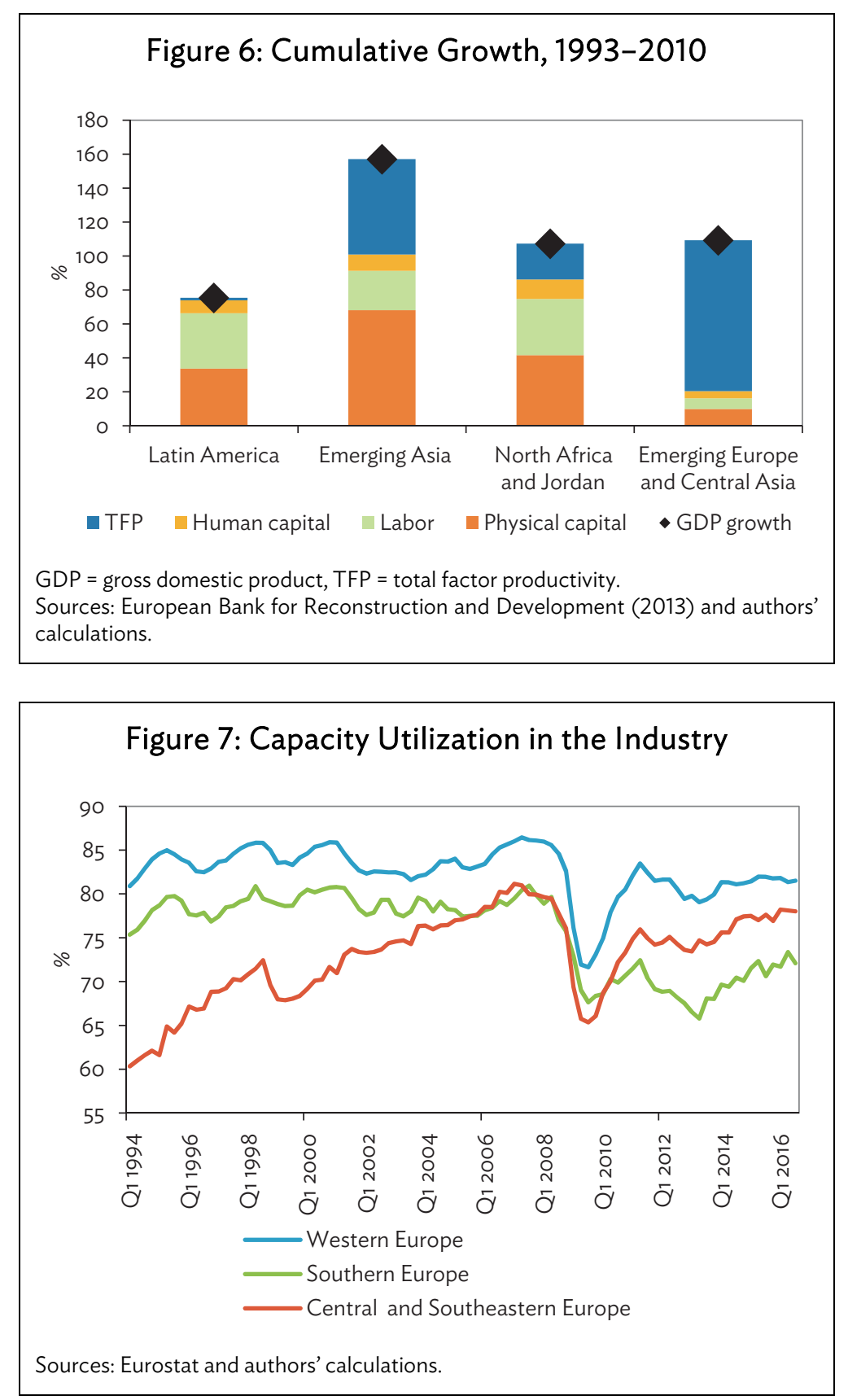

Contributions from labor and human capital are estimated to have been very modest in contrast as populations often shrank due to low fertility, higher mortality during the early years of transition, and high outward migration in many countries in the region. Contribution of physical capital is also estimated to have been small, reflecting relatively high stock of capital at the start of transition.

In emerging Asia, improvements in TFP also made an important contribution to growth over the same period. At the same time, a roughly similar contribution also came from investment in physical 
capital, resulting in an even faster rate of income convergence. In Latin America and North Africa, increases in labor and physical capital played a key role. Contribution of TFP is estimated to have been particularly small in the case of Latin America, reflected in a more modest rate of economic growth overall.

\section{Quantifying the Impact of Structural Reforms}

A number of studies quantify the link between gains in productivity underpinning rapid economic growth in Emerging Europe and Central Asia between the mid-1990s and the 2008-2009 crisis and the radical structural transformations in the region. Evidence suggests that during this period, progress in structural reforms-reforms that go beyond measures aimed purely at managing the economic cyclesignificantly affected subsequent growth, and stronger growth, in turn, supported the reform momentum across emerging Europe and Central Asia. This can be seen by examining structural reform indicators compiled by the EBRD. These "transition indicators" track annual progress in the areas of large-scale privatization, corporate governance and enterprise restructuring, small-scale privatization, price liberalization, trade liberalization, and competition policy. Until 2010, reform scores were also awarded in the areas of banking sector reform, nonbank financial sector, roads, railroads, power, municipal infrastructure, and telecommunication. The scores are recorded on a 10-point scale from 1 (no progress) to 4.33 with a notch of $0.33 .{ }^{2}$ For a description of scores, see the Appendix.

Comprehensive (even if not complete) reform in a certain area is found to give a persistent boost of around 0.8 percentage points to a country's annual growth rate. ${ }^{3}$ The impact of reforms is typically realized with a lag of around 1 year (Falcetti, Lysenko, and Sanfey 2006).

Progress in specific structural reforms is closely linked with general improvements in the quality of the business environment. Yet specific structural reforms had greater power in terms of explaining differences in growth performance of the transition economies in the 1990s than general measures of corruption or the quality of economic institutions. (See Abed and Davoodi [2000] for discussion and evidence.)

Over time, the average EBRD transition indicator became more closely correlated with the quality of institutions (broadly defined as the rules of the same in a society [North 1990]) and specifically their measures such as Worldwide Governance Indicators (WGI) (Kaufmann, Kraay, and Mastruzzi 2009) or the Doing Business indicators published by the World Bank. In 1996, when the first vintage of WGI was released, the correlation between the average of the four economic WGI (rule of law, control of corruption, government effectiveness, and regulatory quality) and the country-level transition indicators was far from perfect, around 0.7 (Figure 8). By 2014, it increased to around 0.9 (Figure 9).

2 The exception is the first notch, whereby the score of 1 is followed by 1.67.

3 Comprehensive reforms are defined as those corresponding to an increase of around 2.5 points on a scale where a maximum increase is of 3.3 points. See Section II.C for a description of the measurement of reforms. 
Figure 8: Average Transition Indicators and World Governance Indicators, 1996

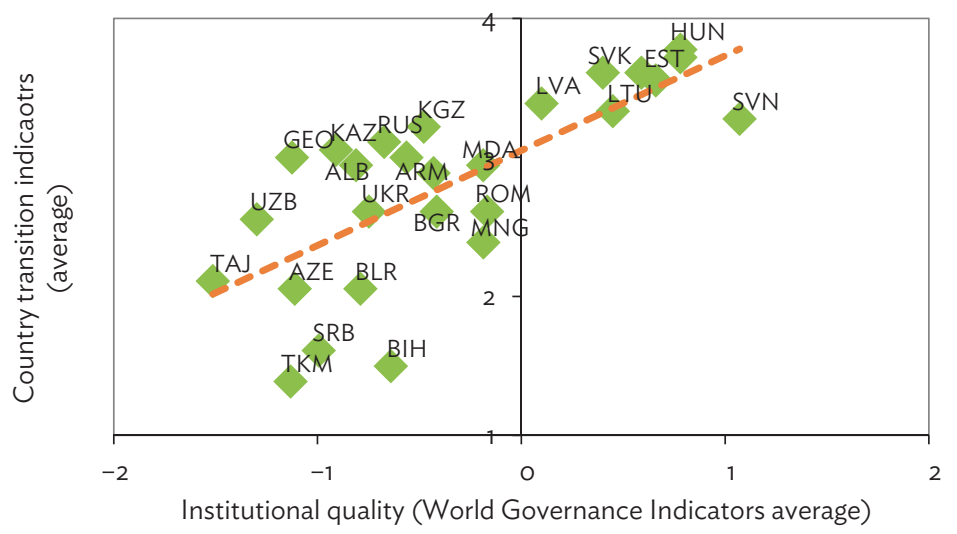

$\mathrm{ALB}=$ Albania, $\mathrm{ARM}=$ Armenia, $\mathrm{AZE}=$ Azerbaijan, $\mathrm{BIH}=$ Bosnia and Herzegovina, $\mathrm{BGR}$ $=$ Bulgaria, $\mathrm{BLR}=$ Belarus, EST $=$ Estonia, $\mathrm{GEO}=$ Georgia, $\mathrm{HUN}=$ Hungary, KAZ = Kazakhstan, KGZ = Kyrgyz Republic, LTU = Lithuania, LVA = Latvia, MDA = Moldova, $M N G=$ Mongolia, $R O M=$ Romania, $R U S=$ Russian Federation, SRB = Serbia, SVK = Slovak Republic, SVN = Slovenia, $T A J=$ Tajikistan,

TKM = Turkmenistan, UKR = Ukraine, UZB = Uzbekistan.

Note: World Governance Indicators are the average of the rule of law, control of corruption, government effectiveness, and regulatory quality.

Sources: World Bank, European Bank for Reconstruction and Development, and authors' calculations.

Figure 9: Average Transition Indicators and World Governance Indicators, 2014

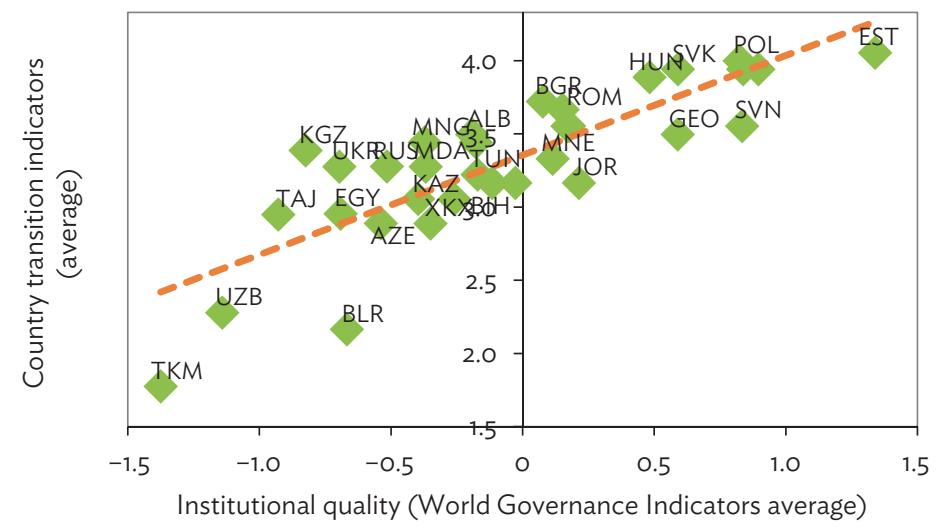

$\mathrm{ALB}=$ Albania, $\mathrm{ARM}=$ Armenia, $\mathrm{AZE}=$ Azerbaijan, $\mathrm{BIH}=$ Bosnia and Herzegovina, $\mathrm{BGR}=$ Bulgaria, $\mathrm{BLR}=$ Belarus, $\mathrm{EGY}=$ Egypt, $\mathrm{EST}=$ Estonia, $\mathrm{GEO}=\mathrm{Georgia}$, $\mathrm{HUN}=$ Hungary, JOR = Jordan, KAZ = Kazakhstan, $\mathrm{KGZ}=$ Kyrgyz Republic, $\mathrm{KSV}=$ Kosovo, $\mathrm{LTU}=$ Lithuania, $\mathrm{LVA}=$ Latvia, MDA = Moldova, MNE = Montenegro, $\mathrm{POL}=$ Poland, $\mathrm{ROM}=$ Romania, $\mathrm{RUS}=$ Russian Federation, $\mathrm{SRB}=$ Serbia, $\mathrm{SVK}=$ Slovak Republic, SVN = Slovenia, $T A J=$ Tajikistan, $T K M=$ Turkmenistan, UKR = Ukraine, UZB = Uzbekistan.

Note: World Governance Indicators are the average of the rule of law, control of corruption, government effectiveness, and regulatory quality.

Sources: World Bank, European Bank for Reconstruction and Development, and authors' calculations. 
Further improvements in the quality of key economic institutions such as rule of law or control of corruption, which would close half of the gap between the levels of the countries in emerging Europe and Central Asia and the average levels in the EU-15 economies, could boost annual growth in the region by around 1 percentage point a year, based on historical trends reflected in panel growth regressions estimated by generalized method of moments (EBRD 2013 and Figure 10).

Figure 10: Evolution of Gross Domestic Product per Worker in Baseline and Reform Scenarios

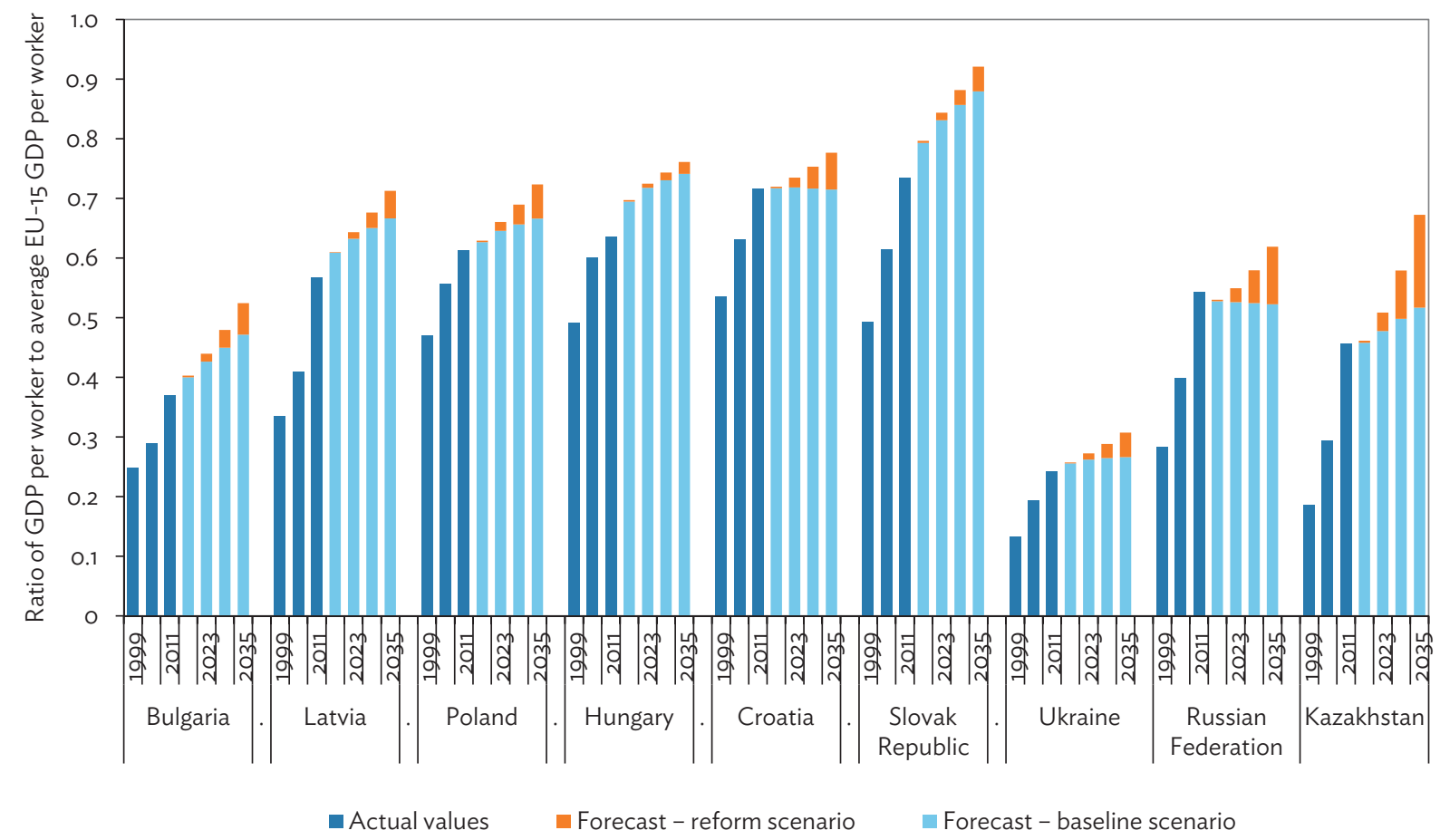

$\mathrm{EU}=$ European Union, GDP = gross domestic product.

Notes: The reform scenario assumes an improvement in the average Worldwide Governance Indicators closing half of the gap in terms of perceived quality of economic institutions between the respective country and the EU-15 average. The baseline scenario assumes unchanged quality of economic institutions as reflected in the averages of the World Governance Indicators.

Source: European Bank for Reconstruction and Development (2013).

In a broader context, various studies also document the positive impact of structural reforms in liberalizing labor, product, and financial markets on productivity and economic growth. For instance, Bertrand and Kramarz (2002) show that retail trade restrictions inhibit job creation in France. Christiansen, Schindler, and Tressel (2013) highlight the role of trade and financial sector reforms in supporting productivity improvements. Nicoletti and Scarpetta (2003) show that reforms promoting private governance and competition boost multifactor productivity in various sectors in the (more developed) Organisation for Economic Co-operation and Development economies. Prati, Onorato, and Papageorgiu (2013) estimate the economic impact of reforms in agriculture, regulated industries, and international trade as well as financial liberalization, and find that this impact varies depending on the political system and the distance of the technological frontier. See also Syverson (2011) for a survey of internal and external factors that shape firm productivity. Dabla-Norris, Ho, and Kyobe (2016) also highlight that different reforms are needed to boost productivity at different stages of economic development, pointing to the importance of proper sequencing of reforms. 
The next section discusses the nature of transition reforms of the 1990s and the early 2000s in greater detail, while the subsequent section also looks at the distributional consequences of these reforms and their cost in terms of lower life satisfaction.

\section{SPEED AND SEQUENCING OF STRUCTURAL REFORM}

\section{A. Broad Trends}

The former communist countries' transformational experience was unique in that the dismantling of their centralized economic structures meant introducing, from the outset, as much of structural and institutional reforms as it was politically possible. Quite a few, mainly in Central Europe, reformed very fast with "big-bang" type reforms, supported by a twin "bottom-up top-down" transformation process of the EU accession and privatization of production and banking sector assets overwhelmingly to EUbased private companies and banks from the mid-1990s (Dyson 2006, and Bruszt and Campos 2016). Others moved more gradually. In particular, in several Western Balkans countries, Slovenia and Belarus market reforms lagged the progress in terms of broad economic institutions capture by the WGI. In contrast, in Central Asia, the Russian Federation, and the Caucasus market reforms as reflected in the EBRD transition indicators tended to progress faster than the strengthening of overall economic institutions, underpinning the rule of law and control of corruption.

Overall, faster reforms appear to have produced faster growth and less transitional employment costs than slower reforms, with initial conditions and democratic institutions playing important roles (for example, Treisman 2014). That said, transitional catch-up was possible, as the examples of late reformers such as the Slovak Republic or Georgia demonstrate (EBRD 2013).

In Central Europe (which comprises the Czech Republic, Croatia, Estonia, Hungary, Latvia, Lithuania, Poland, the Slovak Republic, and Slovenia), the reforms proceeded swiftly in the early 1990s and, on this measure, slowed down at a level close to the maximum of the indicator scale set at 4.33 (Figure 11). In contrast, in Southeastern Europe (comprising Albania, Bulgaria, Romania, and the former Yugoslavia with the exception of Croatia and Slovenia), reforms initially advanced much slower but continued throughout the first decade of the 21st century. Toward the end of the decade, however, they stalled at the level well short of that of Central Europe.

In the Russian Federation, reforms advanced relatively rapidly at first, but there has been relatively little progress after the 1998 crisis. In Central Asia (comprising Kazakhstan, the Kyrgyz Republic, Tajikistan, Turkmenistan, and Uzbekistan), the reforms have petered out around the same time, but at a lower level of completed transformation, on average. In Eastern Europe (Belarus, Moldova, and Ukraine) and the Caucasus (Armenia, Azerbaijan, and Georgia), the pattern was similar to that of Central Asia until the early years of the 21st century. Subsequently, some reforms advanced further albeit at a slower pace than in the 1990s (for instance, Ukraine's accession to the World Trade Organization was accompanied by some liberalization in the service sector as well as tariff reform). 


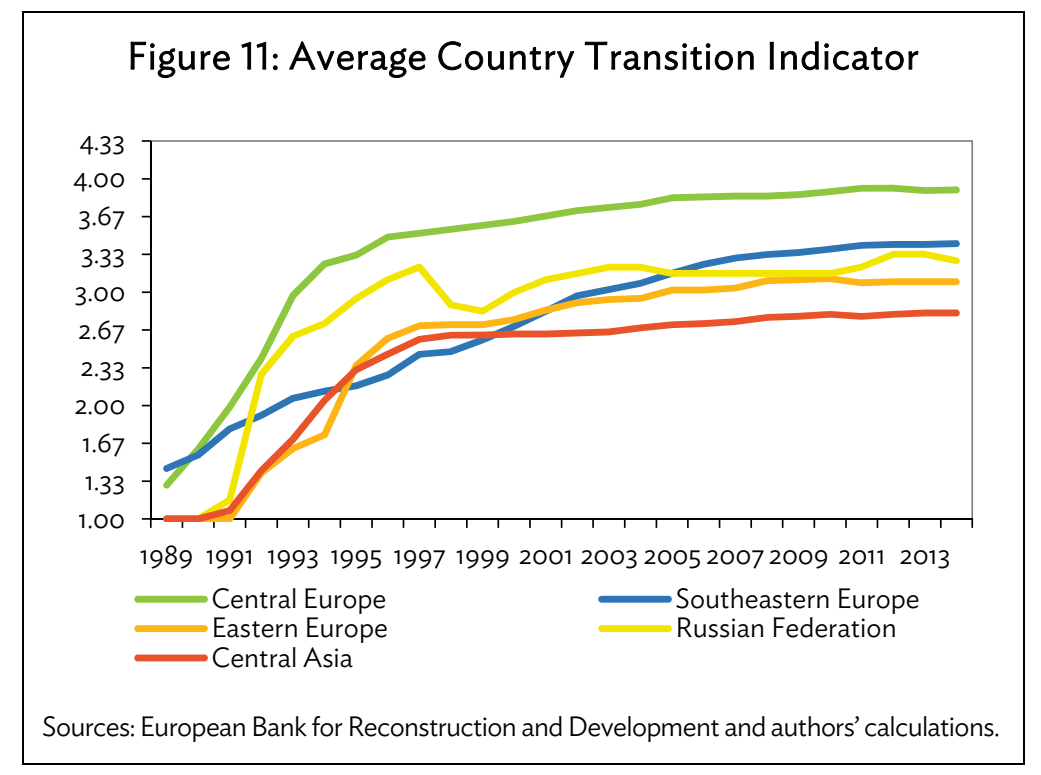

Since 2010, the EBRD has been tracking reforms using a similar methodology, but looking at individual sectors rather than areas of reform (between 13 and 18 sectors in total). This alternative metric shows that reforms continued to advance slowly during this period. Reversals (downgrades in terms of transition indicators) have become common and the balance of upgrades and downgrades is showing no clear trend (Figure 12). In fact, the balance of positive and negative changes was close to zero in 2016, the last available year, after turning negative briefly in 2014.

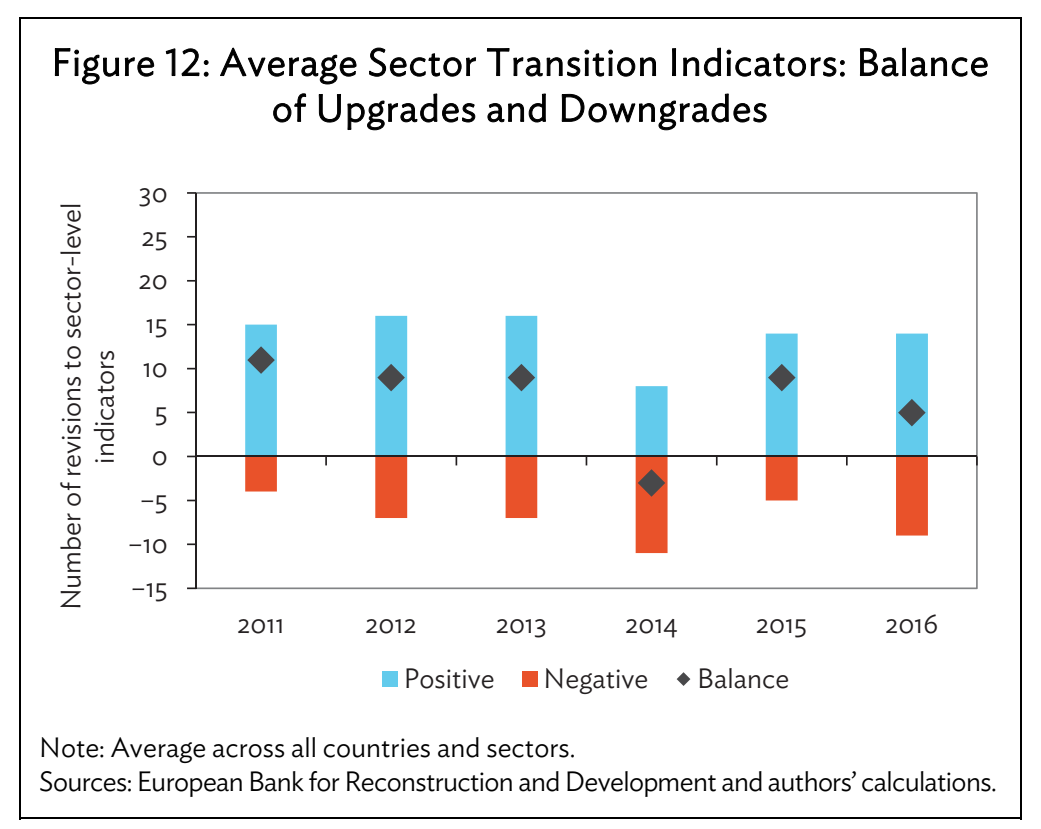

Economic reforms during the early years of transition went hand-in-hand with reforms aimed at strengthening democratic institutions, and the quality of economic and political institutions remained strongly positively correlated (EBRD 2013). This is consistent with the findings of Giuliano, Mishra, and Spilimbergo (2013) who report that, in a broad sample of countries, reforms are more likely to take place in democracies. Reforms have, in turn, an impact on democratization as they strengthen the position of core constituencies for democratization such as entrepreneurs and small and medium-sized enterprises. 


\section{B. Generations of Reforms}

Within countries, different reforms advanced at different speeds. The so-called "first-generation" (market-enabling) reforms-small-scale privatization and liberalization of prices, interest rates, and international trade-have been implemented relatively fast. In many cases, these reforms were completed (in Central Europe) or significantly advanced (in Southeastern Europe) in a span of several years (Figure 13).

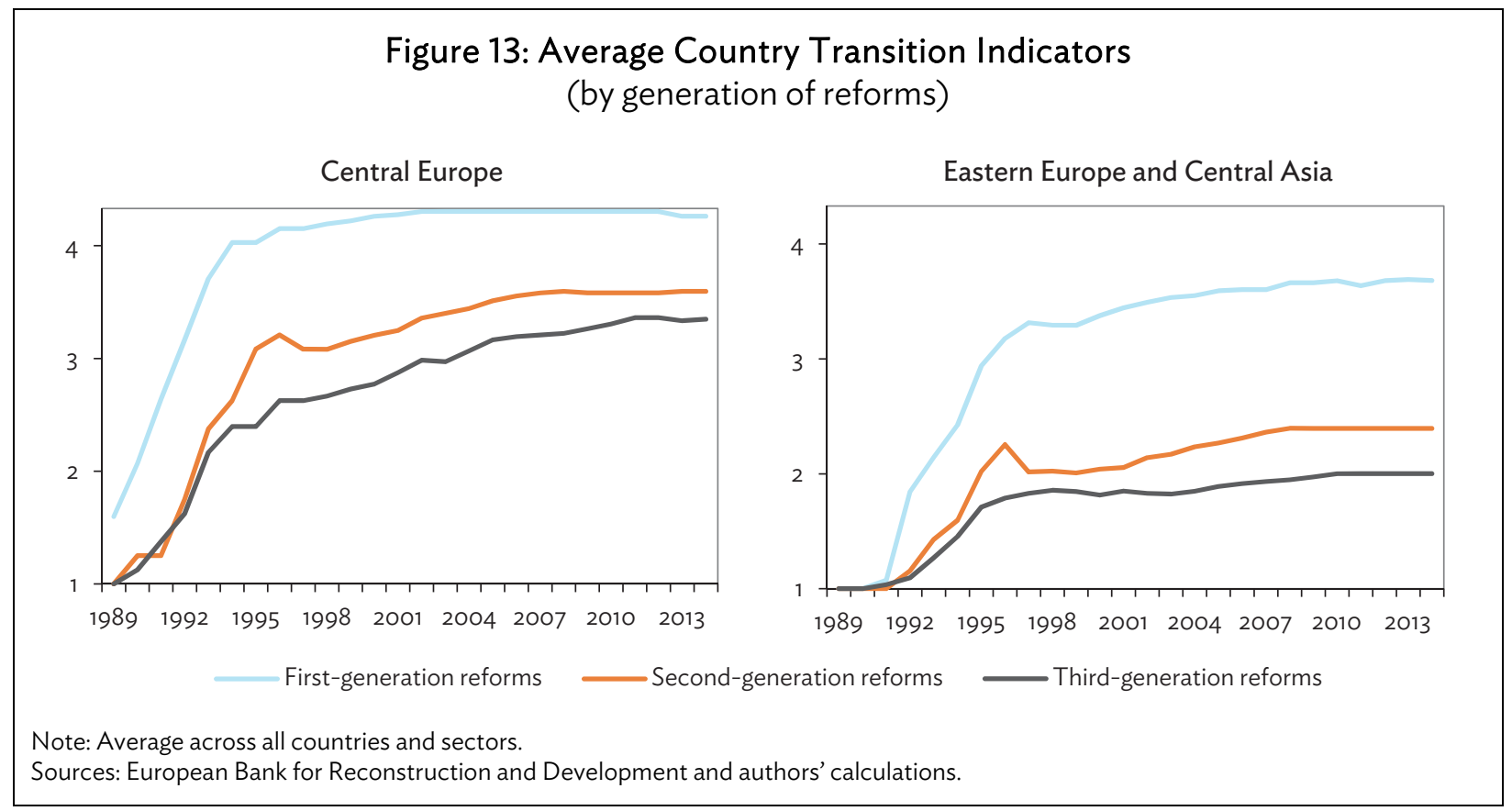

The second generation of reforms, the so-called market-deepening measures, involved largescale privatization and establishing the main underpinnings of a commercial banking sector and capital markets. In Central Europe and later in parts of Southeastern Europe, these reforms were boosted by the countries' accession to the European Union, or firmer prospects of the accession. These reforms were started around the same time as first-generation reforms but remained less advanced in all countries. In Central Asia, Eastern Europe, and the Russian Federation, the gap between the extent of completion of first- and second-generation reforms remains larger than in Central and Southeastern Europe.

The third generation of reforms, the so-called market-sustaining reforms, focused on the creation of key economic institutions underpinning corporate governance and enterprise restructuring, competition policy, property rights and contract enforcement, as well as framework for regulated sectors and public-private partnerships in infrastructure. These were typically implemented later, starting in the mid-1990s, and with greater variation across countries. In many countries, they remain largely incomplete, although the same is perhaps true of a number of advanced economies.

\section{Generations of Reform in a Neo-Schumpeterian Perspective}

In general terms, the timing and extent of completion of structural reforms in transition economies of emerging Europe and Central Asia have been broadly consistent with the neo-Schumpeterian approach, which argues that reform priorities and returns to reforms depend on countries' distance to the 
technological frontier (see, for instance, Acemoglu, Aghion, and Zilibotti 2006). Countries further away from the frontier improve productivity predominantly through import of technologies, and should thus focus on reforms improving the overall business environment, promoting openness to trade and investment, and upgrading basic skills.

In a large sample of countries, Dabla-Norris, Ho, and Kyobe (2016) find that the impact of structural reform varies by quartile of income per capita into which a country falls, and thus depends on a country's distance to the technological frontier. Although the pattern is not always clear-cut, lowerincome countries appear to benefit from generation 1 reforms targeting liberalization of trade and foreign investment. The second generation of reforms concerning labor, product, and financial markets has higher dividends in the case of higher-income countries. Prati, Onorato, and Papageorgiu (2013) also find differential impact of reforms, depending on the distance to the frontier.

Consistent with the neo-Schumpeterian views, generation 1 market reforms in emerging Europe and Central Asia were largely implemented at a time when economies' income per capita in purchasing power parity-adjusted terms was typically around 15\%-30\% of that of the average of the G7 advanced economies. ${ }^{4}$ They were followed by second-generation reforms implemented when economies had already achieved some degree of income convergence. Moreover, generation 2 and generation 3 reforms have advanced to a greater extent in economies with higher per capita incomes (with causality arguably running in both directions: from income levels to completion of reforms, and from structural reforms to faster growth of incomes).

That said, the scope, speed, and sequencing of transformational reforms in former communist countries have had two unique features, particularly in Central Europe:

(i) At the beginning of transformation, structural reforms were frontloaded to an extent that was largely conditioned by political constraints and initial conditions. More reforms were possible in countries where external and domestic incentives for reforms were aligned early on. These were the countries that made it to the high-income group and avoided the middle-income/nonconvergence trap since the beginning of this century: Poland, Czech Republic, Hungary, and Slovakia (with a belated start but strong finish).

(ii) This was an exceptional clustering of middle-income trap-avoiding countries, a phenomenon that may have had to do with a few "leapfrogging" in both policies and institutions of these countries during their transformational process. First, technology transfer in terms of adaptation and imitation was accelerated by the rapid integration of global value chains (GVCs) in advanced EU countries such as Germany and Central Europe (Aiyar et al. 2013). These may have also spurred some "leapfrogging" to technology frontier within these structures in some sectors/firms under GVCs. Outside these structures, imitation of products and processes was generally supported by highlevel foreign ownership and management in the wake of massive privatizations to EUbased firms and banks. Second, institutional reform was also accelerated (leapfrogged) by the requirement of adapting EU (advanced country) legislation as part of the EU accession process ("Acquis Communautaire"). Third, as Bruszt and Campos (2016) point out, deep economic integration can yield gains in state capacities, as was the case in Central Europe, supporting a powerful virtuous circle of cross-border integration and domestic institution reform.

4 The G7 economies comprise Canada, France, Germany, Italy, Japan, the United Kingdom, and the United States. 


\section{Factors Facilitating Structural Reforms}

\section{Economic Integration and European Union Accession}

Far-reaching structural reforms may not be easy to implement as they face opposition from politicians, vested interests, as well as skeptical populations. Economic openness played an important role in anchoring structural reforms throughout the postcommunist period, both directly and indirectly, by contributing to productivity growth and, thus, creating a more accommodative environment for reforms.

While the shares of emerging markets in world output and in global trade generally grew in tandem, European emerging economies came to account for a higher share of global trade compared with their share of the world's GDP (Figure 14). This reflects strong inflows of foreign direct investment (FDI) and active integration of the economies in the European and GVCs. The Slovak Republic is an example of an economy where attracting FDI has been the guiding principle of the wave of reforms that started after the 1998 Asian and the Russian Federation economic crises.

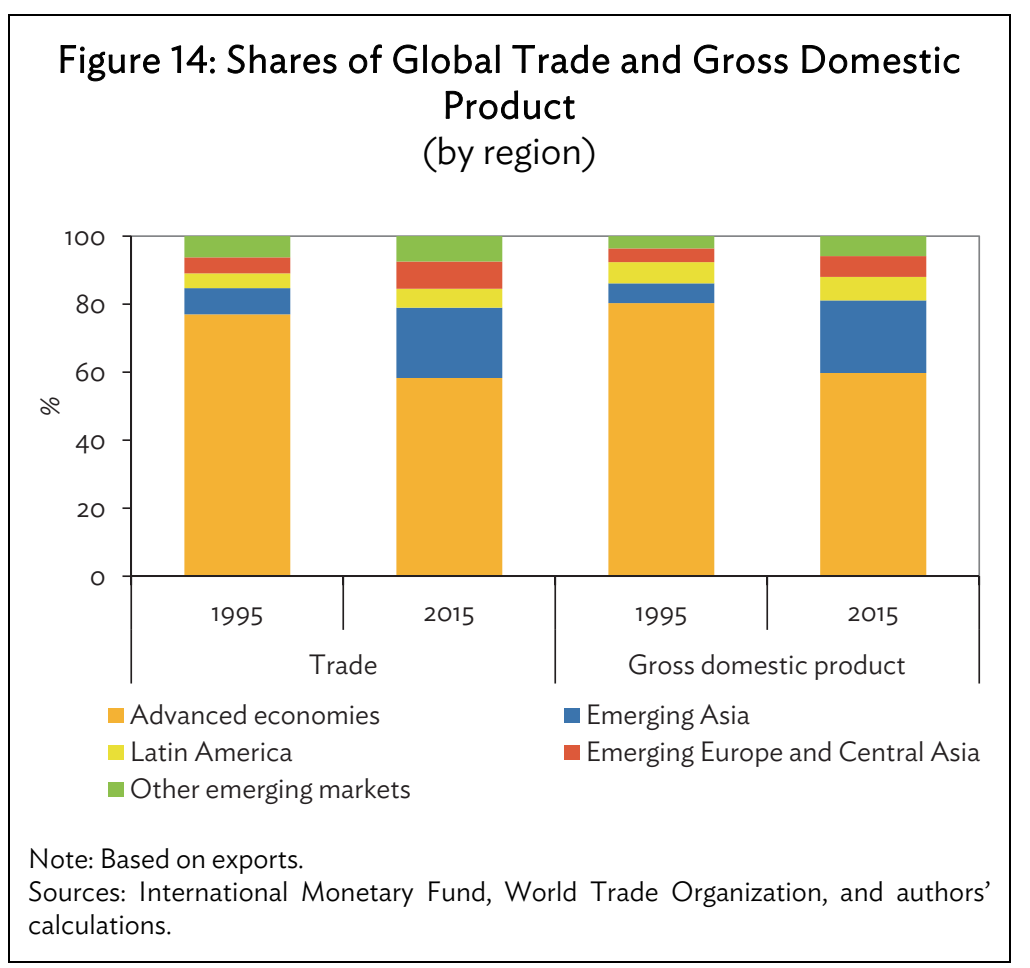

Strikingly, emerging Europe benefited more from the rise in GVCs than emerging Asia, Latina America, or Africa (Figure 15). Expansion of GVCs was an important additional factor, which boosted TFP and economic growth in the 1990s and the following decade, consistent with the finding that economies more open to trade tend to enjoy faster growth (see, for instance, Wacziarg and Welsch 2008; and Christiansen, Schindler, and Tressel 2013). The growth of GVCs has slowed down markedly in the 2010s contributing to the slowdown in growth of global trade observed since 2011. 


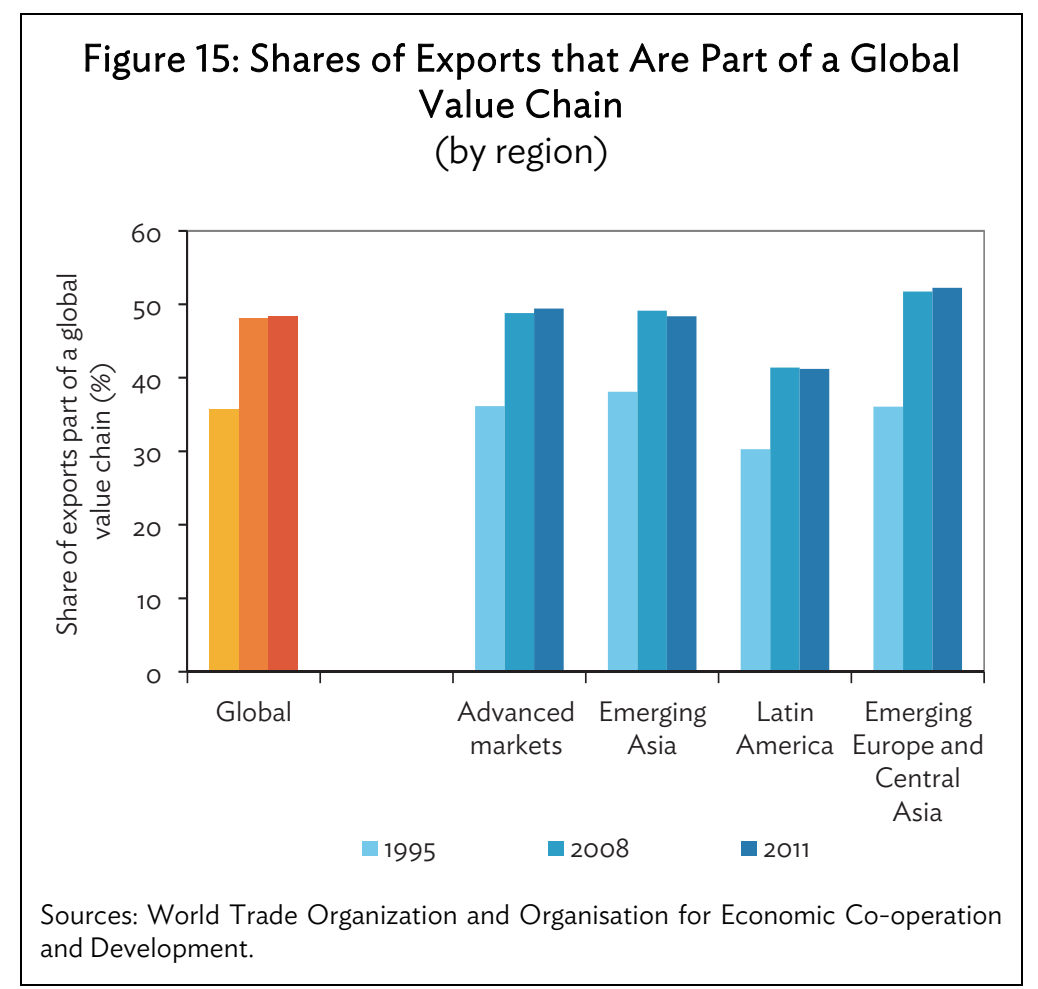

During the period of transition reforms, accession to the EU has been a key driver of trade and investment inflows in Central and Southeastern Europe, and an important anchor of reforms in the region. On average, reforms tended to accelerate in the years leading up to the accession (Figure 16). They also tended to slow down markedly in the subsequent years, once the accession process was complete.

Figure 16: Change in Average Worldwide Governance Indicator

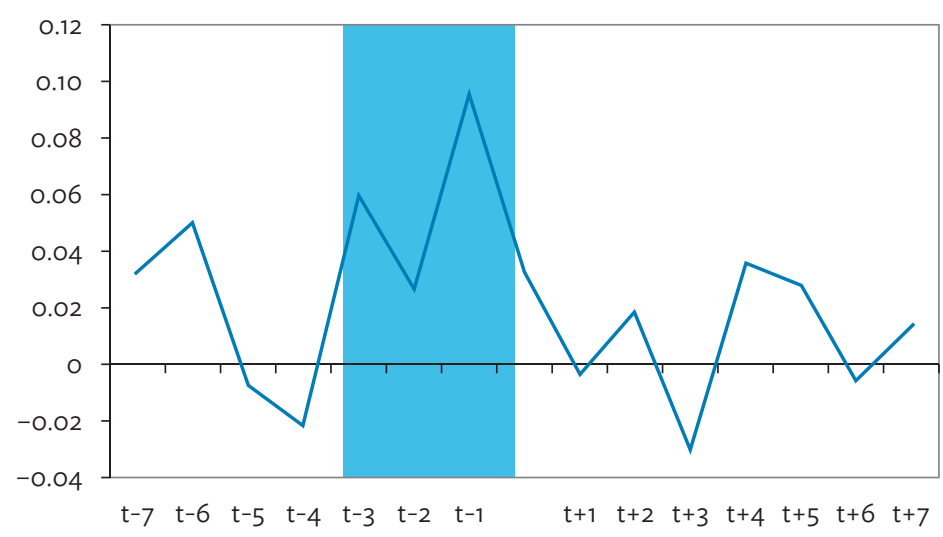

Note: Year 0 corresponds to the year of European Union accession. The indicators are on a $-2.5-2.5$ scale, with a standard deviation of 1 .

Sources: Worldwide Governance Indicators and authors' calculations. 


\section{Foreign Direct Investment and Nonforeign Direct Investment Capital Flows and Foreign Bank Ownership}

In the early years of the 21st century, emerging Europe also saw a period of exceptionally high FDI and non-FDI capital inflows on the back of deeper economic and political integration. The inflows averaged 9\% of recipient countries' GDP during 2002-2008, compared with 4\%-5\% in emerging Asia and 3\%$4 \%$ in Latin America (Figure 17). In part, these inflows facilitated the integration of these economies into Europe and GVCs.

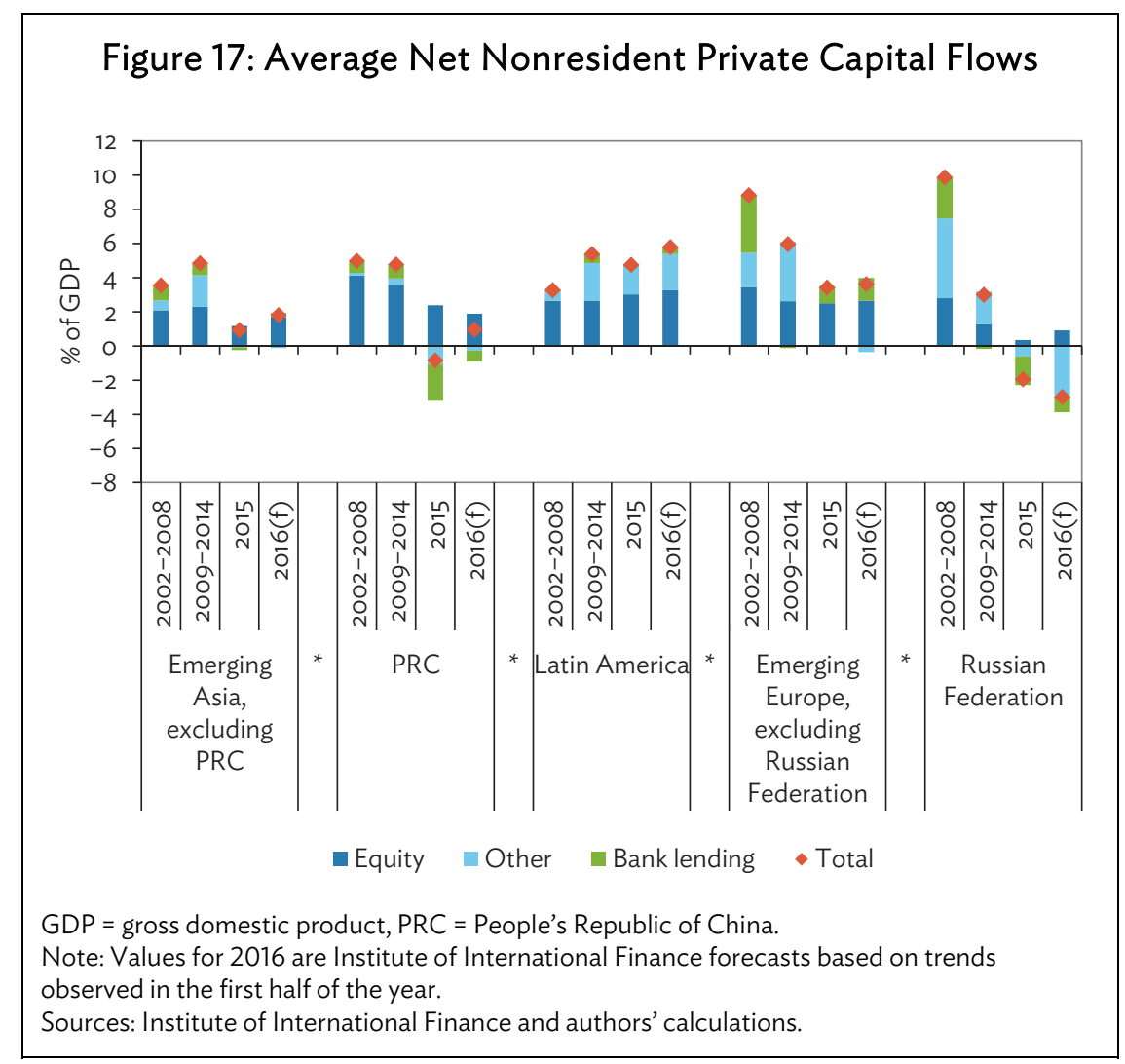

They also reflected the entry of foreign banks (predominantly European) and a sharp increase in the share of foreign banks in total banking assets. By 2009, these shares reached between $60 \%$ and $100 \%$ in many countries in the region (Figure 18). Rapid entry of foreign banks helped technology transfer and capital inflows, but also fueled a domestic credit boom (see, for instance, de Haas and van Lelyveld 2006), widespread lending in foreign currency to unhedged households and small and medium-sized enterprises (see Zettelmeyer, Nagy, and Jeffrey 2010) and thus contributed to the depth of the recession following the 2008-2009 financial crisis. Indeed, as foreign banks have been withdrawing cross-border funds from the region (see de Haas et al. [2015] for a discussion), countries experienced a major credit crunch and protracted episodes of deleveraging.

Ample availability of cross-border finance supported improvements in capital stock and TFP contributing to economic growth. This is in sharp contrast with many experiences of capital inflows into other emerging market regions which, if anything, tended to have negative longer-term growth effects as they have not been accompanied by the same degree of deepening of economic and political ties with "creditor" economies (EBRD 2009; and Friedrich, Schnabel, and Zettelmeyer 2013). 


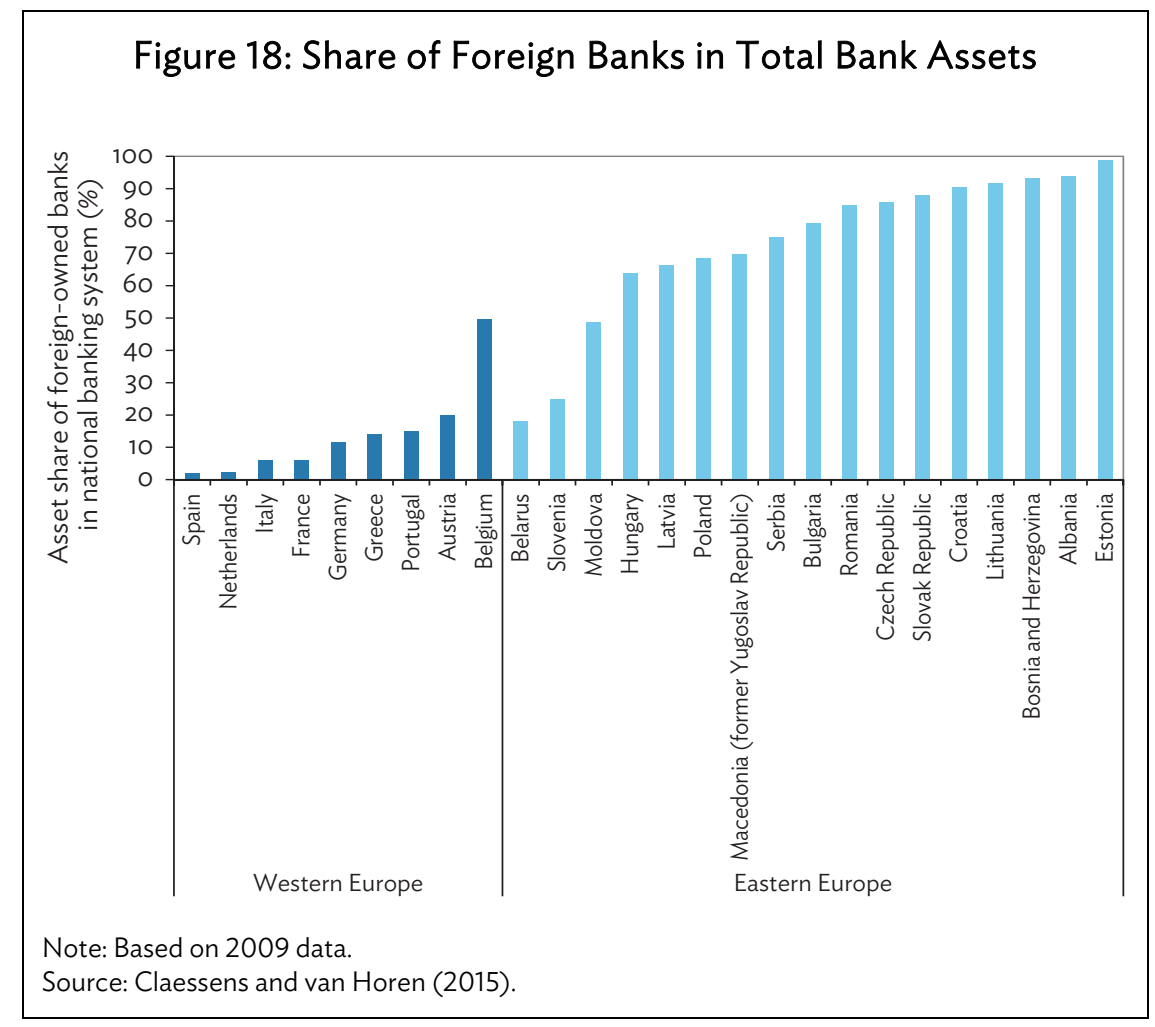

\section{External Anchors Beyond the European Union Membership}

Not all countries in the region had clear prospects of EU accession. Many countries used different external policy benchmarks, such as accession to the World Trade Organization or the Organisation for Economic Co-operation and Development, to anchor certain structural reform agendas.

Since 2008, the Russian Federation has pursued a project to turn Moscow into a major international financial center; a similar goal has been stated by Kazakhstan. A menu of reforms within the financial sector and beyond can increase productivity in the economy regardless of whether the ambition of developing a major financial center is ultimately realized. Examples include legislation supporting derivative transactions or legislation making it easier to hire international experts.

The World Bank Doing Business survey is another example of a useful external benchmark widely used across the region. A number of countries, including Belarus and the Russian Federation, have adopted formal targets in terms of improved Doing Business ratings. Evidence suggests that the resulting "yardstick competition" can be effective (see, for instance, Besley and Case [1995] for evidence from the United States).

The Russian Federation and Kazakhstan subsequently had regional Doing Business surveys conducted to zoom on the intracountry differences in business environment. Evidence suggests that the business environment in large countries in the region indeed varies vastly from region to region (see, for instance, Isakova and Plekhanov [2011]). Grounded in such surveys, review and exchange of best practices among individual regions can help to advance business environment reforms.

The Russian Federation offers an example of the importance of local and regional institutions for the success of economic reform. Between 2001 and 2004, several new laws limited business 
inspections, exempted many activities from licensing requirements, and introduced a notification-based system for firm registration, eliminating the need to wait for authorization from various government agencies. The results differed widely across regions. In some regions, improvements were swift and sizable, according to subsequently conducted surveys. In others (generally regions with weaker governance), firms continued to be inspected far more frequently than legally permitted, licences were still necessary for activities where they were no longer legally required, and authorizations still needed to be sought from various agencies for firms to start operations (see Yakovlev and Zhuravskaya [2013] for evidence and discussion).

The Eurasian Economic Union, a supranational economic project involving Armenia, Belarus, Kazakhstan, the Kyrgyz Republic, and the Russian Federation, may in principle facilitate structural reforms in areas of competencies of supranational bodies (such as competition policy and certain areas of trade policy) although little evidence of this approach being actually pursued is available to date (see Isakova, Koczan, and Plekhanov [2016] for an early discussion).

\section{E. Outlook for Growth and Reform}

The "low-hanging fruit" of TFP convergence has been largely harvested by the time of the 2008-2009 crisis, just as the reform momentum in the region weakened (EBRD 2013). In particular, by 2010 the levels of TFP in the region became indistinguishable from those in other emerging markets with similar per capita income (Figure 19). This means that the region finds itself in need of new sources of growth.

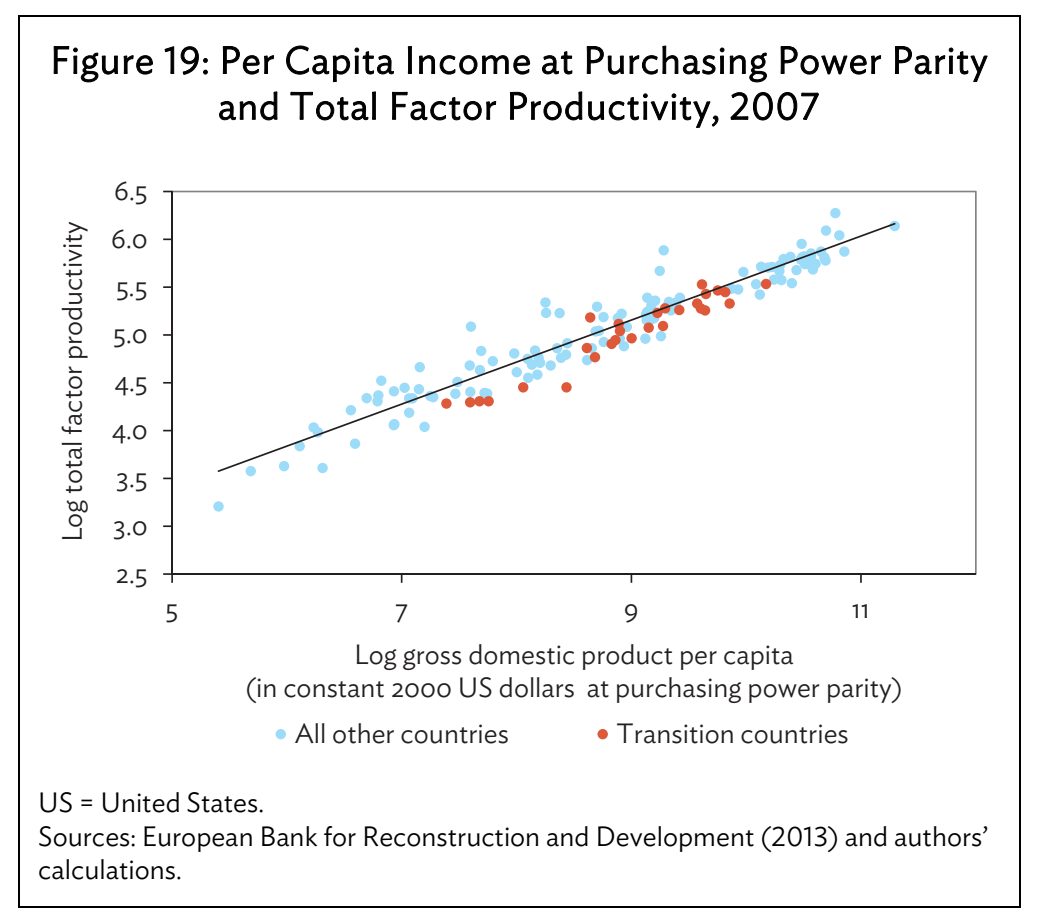

As economies pass the upper-middle-income threshold, weaknesses of economic institutions such as property rights or the rule of law become increasingly important constraints on growth. In particular, institutional deficiencies make it more difficult for countries to shift from imitating technologies to developing and exporting new ideas. Yet support for structural reforms needed to address these obstacles to raising productivity further has weakened, as discussed in the next section. 


\section{STRUCTURAL REFORMS, INEQUALITY, AND LIFE SATISFACTION}

While transition reforms boosted income convergence, they were associated with rising inequality, a drop in life satisfaction as well as physical deprivation during the early years of reform. This section examines the cost of reforms and discusses lessons for sustainability of major structural transformations.

\section{A. Socioeconomic Cost of Transition Reforms}

Recent research suggests that structural reforms may be more effective when implemented in a supportive macroeconomic environment, at least in the case of advanced economies (Eggertsson, Ferrero, and Raffo 2014; and IMF 2016). This is because labor market reforms may strengthen firms' incentives to hire workers in the long term but, at the same time, may negatively affect incumbent workers and, thus, growth of consumption in the short term. Moreover, they have a particularly strong adverse effect on certain groups of individuals. Supportive external environment or deployment of monetary and fiscal stimulus can help to cushion the short-term negative impact of structural reforms on certain population segments (although Caldera, de Serres, and Yashiro [2016], for instance, argue that, even in adverse macroeconomic conditions, structural reforms can be effective).

In the EBRD region, however, on average the reform momentum generally was stronger during years of more challenging economic conditions, whether in terms of weaker growth or higher fiscal deficit and primary fiscal deficit (net of interest payment). This is a combination of diverging trends during the later and the earlier time periods.

During the later period (2000-2014, after the Asian and the Russian Federation crises of 19971998), greater progress in reforms was indeed associated with stronger fiscal balances. A regression of the annual change in transition indicators on country fixed effects, year fixed effects growth rates, and primary fiscal balances suggests that a 1 percentage point improvement in the fiscal stance is associated with a greater incidence of structural reforms representing a marginal increase of 0.04 of a standard deviation of the annual change (Table 1).

Structural Reforms and Fiscal Stance, 2000-2014

\begin{tabular}{lc}
\hline Variable & Change in Transition Indicator (annual) \\
\hline Fiscal balance (\% of GDP) & $0.002^{* *}$ \\
& $(0.001)$ \\
& 0.001 \\
GDP annual growth rate (\%) & $(0.001)$ \\
& $0.062^{* * *}$ \\
Constant & $(0.013)$ \\
& 419 \\
Number of observations & 34 \\
Number of groups & 0.110 \\
$R^{2}$ measure of fit & \\
\hline GDP $=$ gross domestic product. \\
Notea: Specification controls for time and country fixed effects. Standard errors in parentheses \\
and ${ }^{* * * * *}$ denote values significant at the 5\% and 1\% respectively. \\
Source: Authors' calculations.
\end{tabular}


In contrast, the initial price liberalization and privatization reforms took place against the background of a deep recession. As the existing linkages within the central planning economy were being dismantled, production contracted and real incomes and consumption fell sharply. While the transition recession occurred throughout the region, its depth varied between 10\% in the Czech Republic and 70\% or more in certain Central Asian economies (Figure 20).

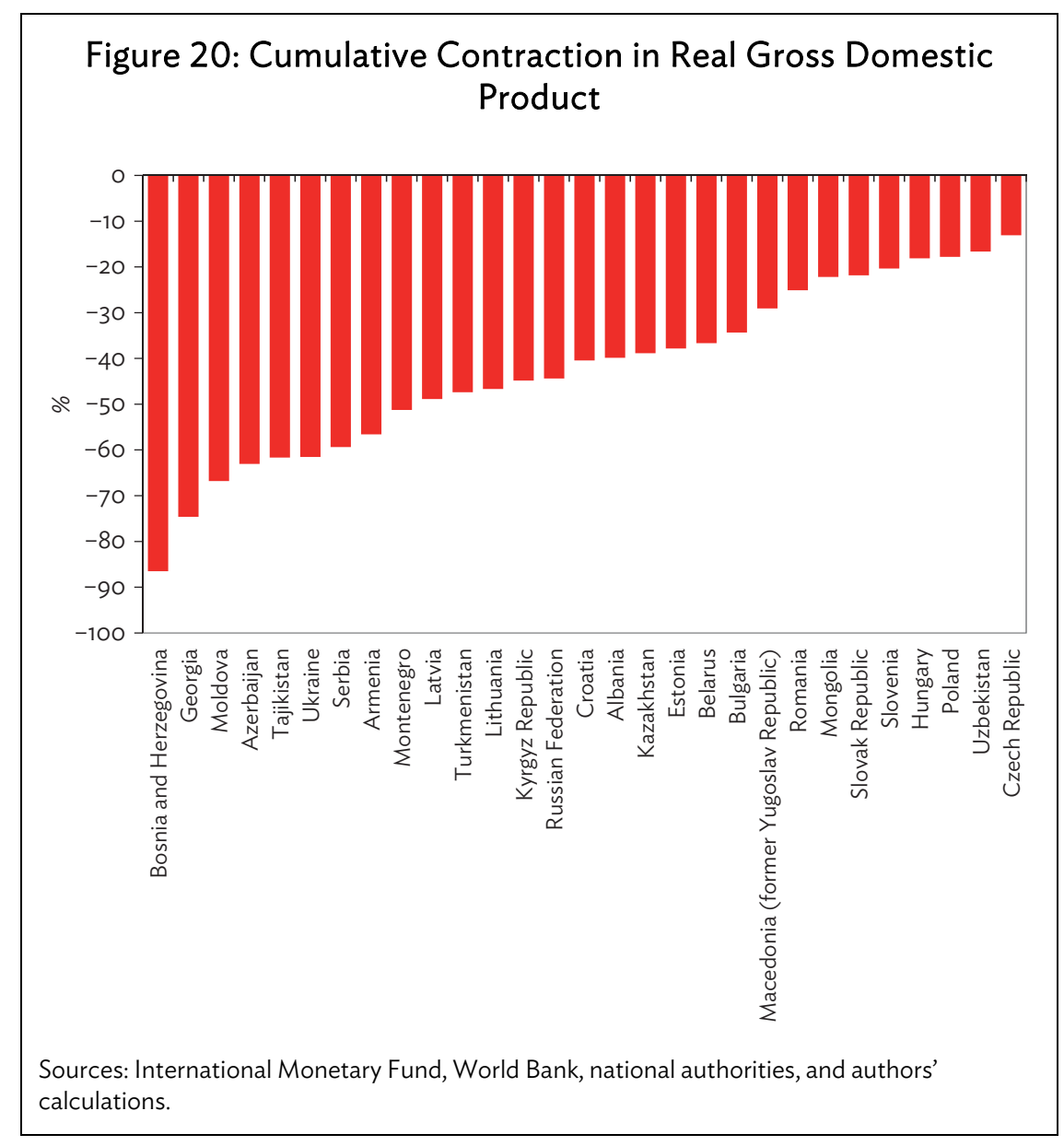

The economic hardship caused by the structural shifts accompanying price liberalization has had long-lasting effects. Adsera et al. (2017) find that people born around the year of price liberalization are on average 1 centimeter shorter than people born before or after (Figure 21). This is equivalent to the effect of being born in a zone of armed conflict and only about one-third of this effect can be explained by the drop in the average per capita income.

Perhaps unsurprisingly, numerous surveys found that economic hardship translated into lower level of life satisfaction in the transition region compared with economies elsewhere that have similar characteristics (Guriev and Zhuravskaya 2009). It took 25 years to overcome this dip in life satisfaction: the latest survey data (the third round of the Life in Transition Survey conducted by the EBRD and the World Bank in late 2015 to early 2016) suggest that the happiness gap has finally closed, more than 2 decades after the start of price liberalization reforms. Today, respondents in the region are, on average, as satisfied with their lives as their counterparts in comparator countries namely, Cyprus, Germany, Greece, Italy, and Turkey (Figure 22). 


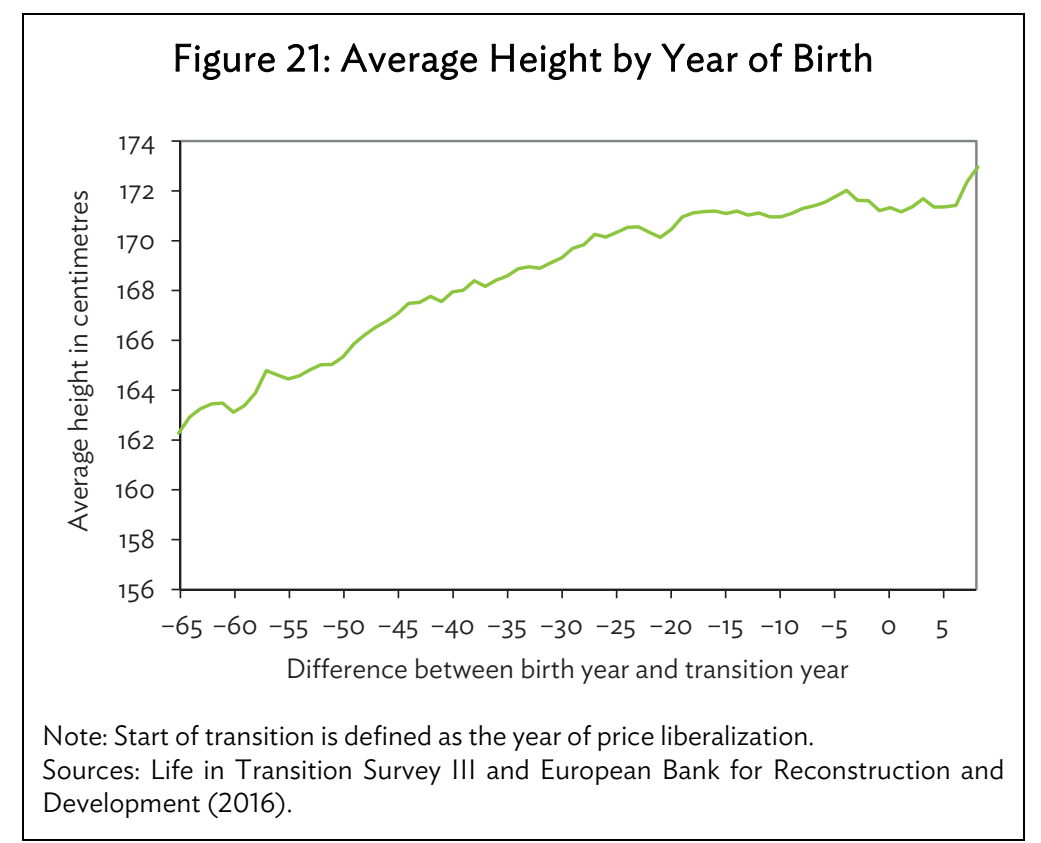

\section{Figure 22: Percentage of Respondents Who Are Satisfied with Life and Per Capita Income}

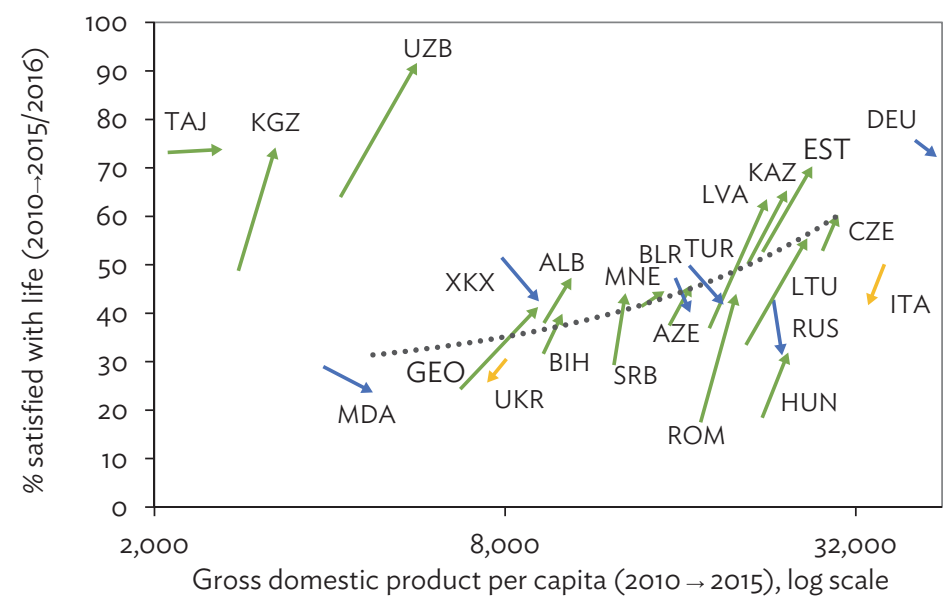

$\mathrm{ALB}=$ Albania, $\mathrm{AZE}=$ Azerbaijan, $\mathrm{BIH}=$ Bosnia and Herzegovina, $\mathrm{BLR}=$ Belarus, $\mathrm{CZE}=$ Czech Republic, DEU = Germany, EST = Estonia, GEO = Georgia, HUN = Hungary, ITA = Italy, KAZ = Kazakhstan, $K G Z=$ Kyrgyz Republic, LTU = Lithuania, LVA = Latvia, MDA = Moldova, MNE = Montenegro, ROM = Romania, RUS = Russian Federation, $S E R=$ Serbia, $T A J=$ Tajikistan, TUR = Turkey, UKR = Ukraine, UZB = Uzbekistan, $\mathrm{XKX}=$ Kosovo. Source: European Bank for Reconstruction and Development (2016).

\section{B. Structural Reforms and Inequality}

Market-oriented reforms in emerging Europe and Central Asia also led to a rise in income and wealth inequality (see, for instance, Guriev and Rachinsky [2006]). Some of this increase in inequality has been inevitable and desirable. It was meant to create stronger links between individuals' efforts and rewards, 
and strengthen incentives to pursue entrepreneurial ideas and excel. Yet the sharp rise in equality had a profound impact on public support for market reforms and democracy.

It may to a large extent explain the strengthening pushback against market reforms in parts of the region over the past decade. The experience highlights the importance of taking into account the distributional effects of structural reforms, as losers (even if they are a minority) tend to have a louder political voice than the beneficiaries of reforms. It is crucial to compensate the losing side, to the extent possible, in the short term, even if in the very long run everyone is perceived to benefit from the structural transformation.

Indeed, certain reforms may substantially lift the average rate of per capita income growth, while benefiting only a minority of the population, at least over a horizon of 1 or 2 decades. In emerging Europe and Central Asia, for instance, each country's headline income growth since the start of transition is estimated to correspond, on average, to the experience of someone around the 75th percentile of the income distribution. By the same token, three quarters of the population have experienced a slower growth (Figure 23 and EBRD 2016). More than 20\% have incomes notionally below those in 1989. In contrast, in Egypt, Jordan, Tunisia, and Turkey, the median citizen experienced income growth above average.

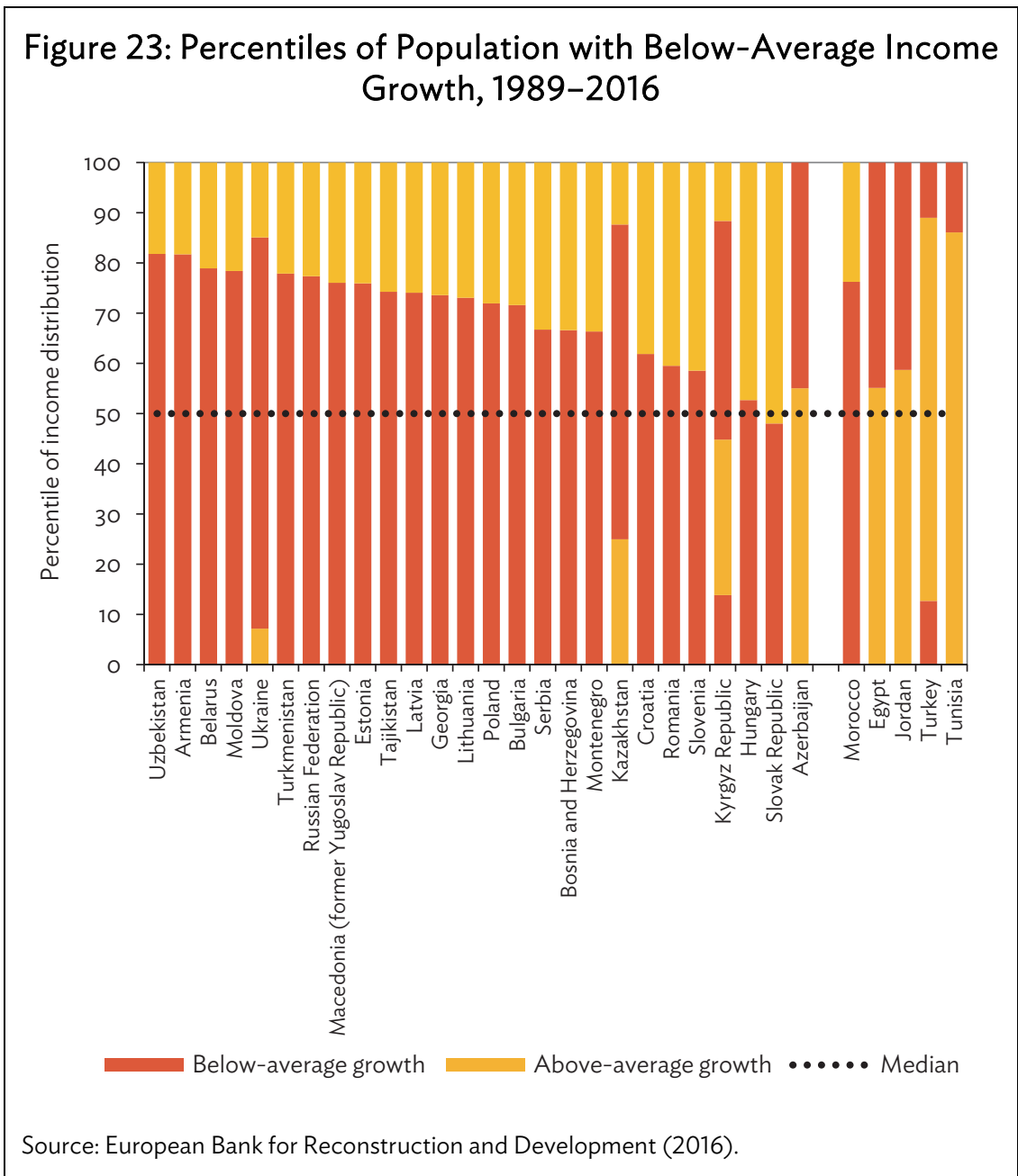


While insightful, these calculations are subject to numerous caveats. In particular, people's ability to spend money under central planning varied vastly and was often based on job-related privileges-something not reflected in the official inequality statistics. And under certain circumstances, structural reforms may in fact contribute to lowering inequality, in particular if they improve economic opportunities, notably access to education and jobs. For instance, Spilimbergo and Che (2012) find that structural reforms tend to promote convergence between different regions within an economy. In sum, reforms need to be evaluated carefully both in terms of their average impact and in terms of their distributional consequences.

\section{CONCLUSION}

This paper examined the experience with structural reforms in emerging Europe and Central Asia since the start of transition from planned to market economy taking into account the most recent developments following the 2008-2009 global financial crisis.

Simultaneous and historically rapid market-oriented structural reforms and institutional transformations played crucial roles in supporting income convergence in the region's economies toward the income levels of advanced countries. The effect has been particularly strong during the period when TFP levels in the region were low relative to countries' endowments of labor, human capital, and physical capital, as well as their levels of per capita income. The first- and second-generation market reforms played an important role in supporting convergence, as did economic and political integrations in the context of accession of economies in Central and Southeastern Europe to the EU. The result was the emergence of a "cluster" of countries in Central Europe that managed to jointly avoid the middleincome or nonconvergence trap, and enter the club of high-income countries. The EU accession, integration of countries into global value chains, and strong capital inflows facilitated reforms, supported improvement in terms of the quality of institutions, and amplified the economic effect of reforms.

However, reforms were associated with significant hardship, in particular during the early years of transition. People born around the year of price liberalization are around 1 centimeter shorter, on average, than those born before or after, an effect comparable with that of being born during an armed conflict. The transition also had a profound impact on the average degree of life satisfaction. It took around 2 and $1 / 2$ decades for the happiness gap between the economies in the region and other emerging markets with comparable characteristics to close.

The increase in inequality from the notionally low levels that prevailed throughout the region under central planning also meant that, for most people, the rates of income growth that they personally experienced have been considerably lower than the averages reported in the national accounts for their respective countries. Over time, this contributed to the substantial weakening of support for market and institutional reforms, with nonnegligible risks of backsliding.

Designing and implementing further structural reforms that appropriately correspond to the level of development-distance to frontier-are likely to present greater challenges. As support for markets and democracy in parts of the region has been weakening, particular attention needs to be paid to distributional consequences of reforms. 


\section{Implications for Emerging Markets in Asia and Elsewhere}

Emerging Europe's experience holds lessons for other emerging markets, in Asia and elsewhere.

First, the region's experience suggests that a unique comparative advantage that underpins rapid growth can be negated by economic convergence within a decade or 2 . In the case of emerging Europe, this advantage was relatively high levels of physical and human capital relative to TFP. For many countries in emerging Asia, this is relatively cheap labor, often English speaking, and countries' locations on major shipping routes. As rapid growth and convergence naturally erode such advantages (by closing the gap in terms of TFP or in terms of workers' pay relative to their productivity), the economic model underpinning convergence needs to adjust and such adjustment requires change of economic policies.

Second, emerging Europe experienced structural transformation on a uniquely large scale. It came with substantial hardship in the short run, but paid off in terms of growth dividends in the long run. For more localized structural reforms, the payoff period may be shorter but a period of hardship may still ensue.

Third, structural transformation entailed increase in inequality and resulted in highly uneven distribution of economic dividends. This, over time, led to the weakening of public support for reform, a more modest reform momentum and the rise of populist politicians in a number of countries. In emerging Asia, the inequality pattern has been similar, but the levels of growth in many countries have been fairly high even for the worse off. If growth slows, support for structural reforms may weaken unless dividends of growth become shared more widely. Indeed, in countries with relatively more modest longterm growth performance, such as the Philippines, political populism has been on the rise. This underscores the importance of designing growth policies with the short-term distributional impact in mind, thus ensuring that support for the growth agenda is not eroded and the strengthening of economic institutions continues.

Fourth, as economies pass the upper-middle-income threshold, weaknesses of economic institutions such as property rights, the rule of law, and the quality of governance become increasingly important constraints in terms of economic convergence, largely because institutional deficiencies make it more difficult for countries to move from being recipients and utilizers of knowledge to becoming creators and exporters of ideas. 


\section{APPENDIX: TRANSITION INDICATORS}

\section{Large-scale privatization}

1 Little private ownership

2 Comprehensive scheme almost ready for implementation; some sales completed

3 More than $25 \%$ of large-scale enterprise assets in private hands or in the process of being privatized (with the process having reached a stage at which the state has effectively ceded its ownership rights), but possibly with major unresolved issues regarding corporate governance

4 More than $50 \%$ of state-owned enterprise and farm assets in private ownership and significant progress with corporate governance of these enterprises

$4+$ Standards and performance typical of advanced industrial economies: more than $75 \%$ of enterprise assets in private ownership with effective corporate governance

\section{Small-scale privatization}

1 Little progress

2 Substantial share privatized

3 Comprehensive program almost ready for implementation

4 Complete privatization of small companies with tradable ownership rights

4+ Standards and performance typical of advanced industrial economies: no state ownership of small enterprises; effective tradability of land

\section{Governance and enterprise restructuring}

1 Soft budget constraints (lax credit and subsidy policies weakening financial discipline at the enterprise level); few other reforms to promote corporate governance

2 Moderately tight credit and subsidy policy, but weak enforcement of bankruptcy legislation and little action taken to strengthen competition and corporate governance

3 Significant and sustained actions to harden budget constraints and to promote corporate governance effectively (for example, privatization combined with tight credit and subsidy policies and/or enforcement of bankruptcy legislation)

4 Substantial improvement in corporate governance and significant new investment at the enterprise level, including minority holdings by financial investors

4+ Standards and performance typical of advanced industrial economies: effective corporate control exercised through domestic financial institutions and markets, fostering marketdriven restructuring

\section{Price liberalization}

1 Most prices formally controlled by the government

2 Some lifting of price administration; state procurement at nonmarket prices for the majority of product categories

3 Significant progress on price liberalization, but state procurement at nonmarket prices remains substantial

4 Comprehensive price liberalization; state procurement at nonmarket prices largely phased out; only a small number of administered prices remain 
4+ Standards and performance typical of advanced industrial economies: complete price liberalization with no price control outside housing, transport, and natural monopolies

\section{Trade and foreign exchange system}

1 Widespread import and/or export controls or very limited legitimate access to foreign exchange

2 Some liberalization of import and/or export controls; almost full current account convertibility in principle, but with a foreign exchange regime that is not fully transparent (possibly with multiple exchange rates)

3 Removal of almost all quantitative and administrative import and export restrictions; almost full current account convertibility

4 Removal of all quantitative and administrative import and export restrictions (apart from agriculture) and all significant export tariffs; insignificant direct involvement in exports and imports by ministries and state-owned trading companies; no major nonuniformity of customs duties for nonagricultural goods and services; full and current account convertibility

4+ Standards and performance norms of advanced industrial economies: removal of most tariff barriers; membership in World Trade Organization

\section{Competition policy}

1 No competition legislation and institutions

2 Competition policy legislation and institutions set up; some reduction of entry restrictions or enforcement action on dominant firms

3 Some enforcement actions to reduce abuse of market power and to promote a competitive environment, including break-ups of dominant conglomerates; substantial reduction of entry restrictions

4 Significant enforcement actions to reduce abuse of market power and to promote a competitive environment

4+ Standards and performance typical of advanced industrial economies: effective enforcement of competition policy; unrestricted entry to most markets

\section{Banking reform and interest rate liberalization}

1 Little progress beyond establishment of a two-tier system

2 Significant liberalization of interest rates and credit allocation; limited use of directed credit or interest rate ceilings

3 Substantial progress in establishment of bank solvency and of a framework for prudential supervision and regulation; full interest rate liberalization with little preferential access to cheap refinancing; significant lending to private enterprises and significant presence of private banks

4 Significant movement of banking laws and regulations toward Bank for International Settlements standards; well-functioning banking competition and effective prudential supervision; significant term lending to private enterprises; substantial financial deepening

4+ Standards and performance norms of advanced industrial economies: full convergence of banking laws and regulations with Bank for International Settlements standards; provision of full set of competitive banking services 


\section{Securities markets and nonbank financial institutions}

1 Little progress

2 Formation of securities exchanges, market makers, and brokers; some trading in government paper and/or securities; rudimentary legal and regulatory framework for the issuance and trading of securities

3 Substantial issuance of securities by private enterprises; establishment of independent share registries, secure clearance and settlement procedures, and some protection of minority shareholders; emergence of nonbank financial institutions (for example, investment funds, private insurance and pension funds, leasing companies) and associated regulatory framework

4 Securities laws and regulations approaching International Organization of Securities Commissions standards; substantial market liquidity and capitalization; well-functioning nonbank financial institutions and effective regulation

4+ Standards and performance norms of advanced industrial economies: full convergence of securities laws and regulations with International Organization of Securities Commissions standards; fully developed nonbank intermediation

\section{Electric power}

1 Power sector operates as government department with few commercial freedoms or pressures; average prices well below costs, with extensive cross subsidies; monolithic structure, with no separation of different parts of the business

2 Power company distanced from government, but there is still political interference; some attempt to harden budget constraints, but effective tariffs are low; weak management incentives for efficient performance; little institutional reform and minimal, if any, private sector involvement

3 Law passed providing for full-scale restructuring of industry, including vertical unbundling through account separation and set up of regulator; some tariff reform and improvements in revenue collection; some private sector involvement

4 Separation of generation, transmission, and distribution. Independent regulator set up; rules for cost-reflective tariff-setting formulated and implemented; substantial private sector involvement in distribution and/or generation; some degree of liberalization

4+ Tariffs cost reflective and provide adequate incentives for efficiency improvements; largescale private sector involvement in the unbundled and well-regulated sector; fully liberalized sector with well-functioning arrangements for network access and full competition in generation

\section{Railways}

1 Monolithic structure operated as government department, with few commercial freedoms; no private sector involvement and extensive cross subsidization

2 Rail operations distanced from state, but weak commercial objectives; some business planning, but targets are general and tentative; no budgetary funding of public service obligations; ancillary businesses separated, but little divestment; minimal private sector involvement

3 Commercial orientation in rail operations; freight and passenger services separated and some ancillary businesses divested; some budgetary compensation available for passenger 
services; improved business planning with clear investment and rehabilitation targets, but funding unsecured; some private sector involvement in rehabilitation and/or maintenance

4 Railways fully commercialized, with separate internal profit centers for freight and passenger services; extensive market freedoms to set tariffs and investments; implementation of medium-term business plans; ancillary industries divested; private sector participation in freight operation, ancillary services, and track maintenance

4+ Separation of infrastructure freight and passenger operations; full divestment and transfer of asset ownership implemented or planned, including infrastructure and rolling stock; rail regulator established and access pricing implemented

\section{Roads}

1 Minimal degree of decentralization and no commercialization; all regulatory, road management, and resource allocation functions centralized at ministerial level; new investments and road maintenance financing dependent on central budget allocations; road user charges not based on the cost of road use; road construction and maintenance undertaken by public construction units; no public consultation in the preparation of road projects

2 Moderate degree of decentralization and initial steps in commercialization; road/highway agency created; improvements in resource allocation and public procurement; road user charges based on vehicle and fuel taxes, but not linked to road use; road fund established, but dependent on central budget; road construction and maintenance undertaken primarily by corporatized public entities, with some private sector participation; minimal public consultation/participation on road projects

3 Fair degree of decentralization and commercialization; regulation and resource allocation functions separated from road maintenance and operations; level of vehicle and fuel taxes related to road use; private companies able to provide and operate roads under negotiated commercial contracts; private sector participation in road maintenance and/or through concessions to finance, operate, and maintain parts of highway network; limited public consultation/participation and accountability on road projects

4 Large degree of decentralization; transparent methodology used to allocate road expenditures; track record in competitive procurement of road design, construction, maintenance, and operations; large-scale private sector participation in construction, operations, and maintenance directly and through public-private partnerships; substantial public consultation/participation and accountability on road projects

4+ Fully decentralized road administration; commercialized road maintenance operations competitively awarded to private companies; road user charges reflect the full costs of road use and associated factors, such as congestion, accidents, and pollution; widespread private sector participation in all aspects of road provision; full public consultation on new road projects

\section{Telecommunications}

1 Little progress in commercialization and regulation; minimal private sector involvement and strong political interference in management decisions; low tariffs, with extensive cross subsidization; liberalization not envisaged, even for mobile telephony and value-added services

2 Modest progress in commercialization; corporatization of dominant operator and some separation from public sector governance, but tariffs are still politically set 
3 Substantial progress in commercialization and regulation; telecommunications and postal services fully separated; cross subsidies reduced; considerable liberalization in the mobile segment and in value-added services

4 Complete commercialization, including privatization of the dominant operator; comprehensive regulatory and institutional reforms; extensive liberalization of entry

4+ Effective regulation through an independent entity; coherent regulatory and institutional framework to deal with tariffs, interconnection rules, licensing, concession fees, and spectrum allocation; consumer ombudsman function

\section{Water and waste water}

1 Minimal degree of decentralization; no commercialization; services operated as vertically integrated natural monopolies by government ministry or municipal departments; no financial autonomy and/or management capacity at municipal level; low tariffs, low cash collection rates, and high cross subsidies

2 Moderate degree of decentralization; initial steps toward commercialization; services provided by municipally owned companies; partial cost recovery through tariffs; initial steps to reduce cross subsidies; general public guidelines exist regarding tariff setting and service quality, but both under ministerial control; some private sector participation through service or management contacts, or competition to provide ancillary services

3 Fair degree of decentralization and commercialization; water utilities operate with managerial and accounting independence from municipalities, using international accounting standards and management information systems; operating costs recovered through tariffs, with a minimum level of cross subsidies; more detailed rules drawn up in contract documents, specifying tariff review formulae and performance standards; private sector participation through the full concession of a major service in at least one city

4 Large degree of decentralization and commercialization; water utilities managerially independent, with cash flows - net of municipal budget transfers-that ensure financial viability; no cross subsidies; semiautonomous regulatory agency able to advise and enforce tariffs and service quality; substantial private sector participation through concessions, management contacts or asset sales

4+ Water utilities fully decentralized and commercialized; fully autonomous regulator exists with complete authority to review and enforce tariff levels and quality standards; widespread private sector participation via management or lease contracts; high-powered incentives, full concessions and/or divestiture of water and waste-water services in major urban areas 


\section{REFERENCES}

Abed, George T., and Hamid R. Davoodi. 2000. "Corruption, Structural Reforms, and Economic Performance in the Transition Economies." IMF Working Paper 00/132.

Acemoglu, Daron, Philippe Aghion, and Fabrizio Zilibotti. 2006. "Distance to Frontier, Selection, and Economic Growth.” Journal of the European Economic Association 4 (1): 37-74.

Adsera, Alicia, Francesca Dalla Pozza, Sergei Guriev, and Lukas Kleine-Rueschkamp. 2017. "The Impact of Transition on Well-being." EBRD Working Paper. Forthcoming.

Aiyar, Shekhar, Bartek Augustyniak, Christian Ebeke, Ehsan Ebrahimy, Selim Elekdag, Nir Klein, Subir Lall, Hongyan Zhao, and Dirk Muir. 2013. "German-Central European Supply Chain-Cluster Report." IMF Country Report 13/263.

Bertrand, Marianne, and Francise Kramarz. 2002. "Does Entry Regulation Hinder Job Creation? Evidence from the French Retail Industry." Quarterly Journal of Economics 117 (4): 1369-413.

Besley, Timothy, and Anne Case. 1995. "Incumbent Behavior. Vote-Seeking, Tax-Setting, and Yardstick Competition.” American Economic Review 85 (1): 25-45.

Bruszt, Laszlo, and Nauro Campos. 2016. Deep Economic Integration and State Capacity: The Case of the Eastern Enlargement of the European Union. Central European University. Mimeo.

Caldera, Aida, Alain de Serres, and Naomitsu Yashiro. 2016. "Reforming in a Difficult Macroeconomic Environment: A Review of the Issues and Recent Literature.” OECD Working Paper 1297.

Christiansen, Lone, Martin Schindler, and Thierry Tressel. 2013. "Growth and Structural Reforms. A New Assessment." Journal of International Economics 89 (2): 347-56.

Claessens, Stijn, and Neeltje van Horen. 2015. "The Impact of the Global Financial Crisis on Banking Globalization.” IMF Economic Review 63 (4): 868-918.

Dabla-Norris, Era, Giang Ho, and Annette Kyobe. 2016. "Structural Reforms and Productivity Growth in Emerging Market and Developing Economies.” IMF Working Paper 16/15.

De Haas, Ralph, Yevgeniya Korniyenko, Alexander Pivovarsky, and Teodora Tsankova. 2015. "Taming the Herd? Foreign Banks, the Vienna Initiative and Crisis Transmission." Journal of Financial Intermediation 24 (3): 325-55.

De Haas, Ralph, and Iman Van Lelyveld. 2006. "Foreign Banks and Credit Stability in Central and Eastern Europe. A Panel Data Analysis.” Journal of Banking \& Finance 30 (7): 1927-52.

Dyson, Kenneth, ed. 2006. Enlarging the Euro Area: External Empowerment and Domestic Transformation in East Central Europe. Oxford: Oxford University Press.

European Bank for Reconstruction and Development (EBRD). 2009. Recovery and Reform, Transition Report 2009. London. 
2013. Stuck in Transition? Transition Report 2013.

. 2016. Transition for All: Equal Opportunities in an Unequal World. Transition Report 2016-17.

Eggertsson, Gauti, Andrea Ferrero, and Andrea Raffo. 2014. "Can Structural Reforms help Europe?" Journal of Monetary Economics 61: 2-22.

Falcetti, Elisabetta, Tatyana Lysenko, and Peter Sanfey. 2006. "Reforms and Growth in Transition: ReExamining the Evidence." Journal of Comparative Economics 34 (3): 421-45.

Friedrich, Christian, Isabel Schnabel, and Jeromin Zettelmeyer. 2013. Financial Integration and Growth-Why is Emerging Europe Different?" Journal of International Economics 89 (2): 522-38.

Giuliano, Paola, Prachi Mishra, and Antonio Spilimbergo. 2013. "Democracy and Reforms: Evidence from a New Dataset." American Economic Journal: Macroeconomics 5 (4): 179-204.

Guriev, Sergei, and Andrei Rachinsky. 2006. "The Evolution of Personal Wealth in the Former Soviet Union and Central and Eastern Europe." UNU-WIDER Working Paper No. 2006/120.

Guriev, Sergei, and Ekaterina Zhuravskaya. 2009. “(Un)happiness in Transition.” Journal of Economic Perspectives 23 (2): 143-68.

International Monetary Fund (IMF). 2016. Time for a Supply-Side Boost? Macroeconomic Effects of Labor and Product Market Reforms in Advanced Economies. World Economic Outlook, April, Chapter 3. Washington, DC.

Isakova, Asel, Zsoka Koczan, and Alexander Plekhanov. 2016. "How Much Do Tariffs Matter? Evidence from the Customs Union of Belarus, Kazakhstan and Russia." Journal of Economic Policy Reform 19 (2): 166-84.

Isakova, Asel, and Alexander Plekhanov. 2011. "Region-Specific Constraints to Doing Business: Evidence from Russia." Aussenwirtschaft: The Swiss Review of International Economic Relations 66 (2): $181-210$.

Kaufmann, Daniel, Aart Kraay, and Massimo Mastruzzi. 2009. Governance Matters VIII: Governance Indicators for 1996-2008. World Bank Policy Research Working Paper 4978.

Lehne, Jonathan, Jeffrey Mo, and Alexander Plekhanov. 2014. "What Determines the Quality of Economic Institutions? Cross-Country Evidence." EBRD Working Paper 171.

Nicoletti, Giuseppe, and Stefano Scarpetta. 2003. "Regulation, Productivity and Growth: OECD Evidence." Economic Policy 18 (36): 9-72.

North, Douglas. 1990. Institutions, Institutional Change, and Economic Performance. Cambridge: Cambridge University Press. 
Prati, Alessandro, Massimiliano Onorato, and Chris Papageorgiu. 2013. "Which Reforms Work and Under What Institutional Environment? Evidence from a New Dataset on Structural Reform." Review of Economics and Statistics 95 (3): 946-68.

Spilimbergo, Antonio, and Natasha Che. 2012. "Structural Reform and Regional Convergence." IMF Working Paper 12/106.

Syverson, Chad. 2011. "What Determines Productivity?" Journal of Economic Literature 49 (2): 326-65.

Treisman, Daniel. 2014. "The Political Economy of Change after Communism.” In The Great Rebirth: Lessons from the Victory of Capitalism over Communism, edited by Anders Aslund and Simeon Djankov, 273-96. Washington, DC: Peterson Institute for International Economics.

Wacziarg, Romain, and Karen Welsch. 2008. "Trade Liberalization and Growth: New Evidence.” World Bank Economic Observer 22 (2): 187-231.

Yakovlev, Evgeny, and Ekaterina Zhuravskaya. 2013. "The Unequal Enforcement of Liberalization: Evidence from Russia's Reform of Business Regulation." Journal of the European Economic Association 11 (4): 808-38.

Zettelmeyer, Jeromin, Piroska Mohacsi Nagy, and Stephen Jeffrey. 2010. "Addressing Private Sector Currency Mismatches in Emerging Europe.” EBRD Working Paper No. 115. 


\section{Structural Reform and Productivity Growth in Emerging Europe and Central Asia}

What lessons does emerging Europe's convergence experience since the early 1990s hold for emerging Asia? Comprehensive structural transformation lifted total factor productivity (TFP). Yet by the late $2000 \mathrm{~s}$, the TFP catch-up potential had been exhausted. To sustain convergence, greater emphasis is needed on reforms facilitating innovation, boosting firm productivity, and improving equality of economic opportunities.

\section{About the Asian Development Bank}

ADB's vision is an Asia and Pacific region free of poverty. Its mission is to help its developing member countries reduce poverty and improve the quality of life of their people. Despite the region's many successes, it remains home to a large share of the world's poor. ADB is committed to reducing poverty through inclusive economic growth, environmentally sustainable growth, and regional integration.

Based in Manila, ADB is owned by 67 members, including 48 from the region. Its main instruments for helping its developing member countries are policy dialogue, loans, equity investments, guarantees, grants, and technical assistance. 